\title{
BLOOD VOLUME AND OXYGEN CAPACITY IN MAMMALS
}

By

JACK DENNING BURKE

\begin{abstract}
A DISSERTATION PRESENTED TO THE GRADUATE COUNCIL OF
THE UNIVERSITY OF FLORIDA

IN PARTIAL FULFILMENT OF THE REQUIREMENTS FOR THE DEGREE OF DOCTOR OF PHILOSOPHY
\end{abstract}

UNIVERSITY OF FLORIDA

June, 1952 


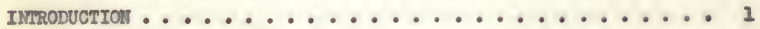

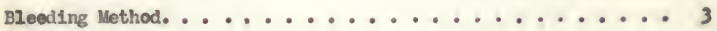

Indirect lothods .................... 4

Obsolete Methods .................

Dye llethods. . . . . . . . . . . . . . 6

Radloset1ve llethods. ............... g

METHODS AND RATRRIAIS UST IN THE PRESENT INVSTIGATION. . . . 12

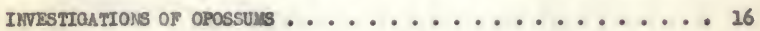

Blood Volume Determinations with $\mathrm{T}-282 \mathrm{~h}$ Dye and $\mathrm{P}-32 \ldots \ldots$

M1xing TIme and Rate of DIsappearence of Dye and P-32. . . . 18

Uptake by Red Blood Calls of P-32. . . . . . . . . 28

Other Data in Regard to the Opossua. ........... 30 BLOOD WOLUE DETERUIMUTION IN OTHER ANTMLS. ........ 32

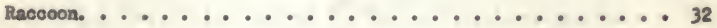

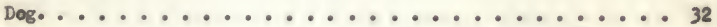

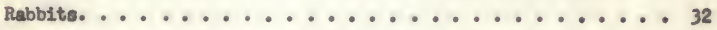

INVETTLATIONS OF DUROC-JRRSET SHINE ............ 34

Blood Volume Determinations with $\mathrm{r}-1824$ Dye and $\mathrm{P}-32 \ldots \ldots . . .34$

Other Date in Regard to Swine. ............... 35

Mring Time and Rate of D1appearance of Dye and P-32. . . 38 BLOOD VOLUIS VALUES FROU AVATLABLE SOURCES . . . . . . . . . 42 DETERACMATION ON OXYYEN CAPACITY OF THE BLOOD. ....... 52

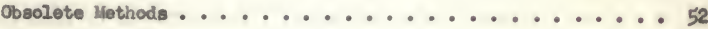


TABLES OF COMTENTS (Continued)

Page

Present Day Methods. ................... 53

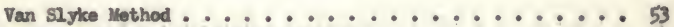

Roughton-Seholander Syringe Method .......... Sh

Oxygen Capacity Determinations of the Present Investigation

with the Syringe Method. ............ 56

Oxygen Capacity Values from Available Sources. . . . . . . 61

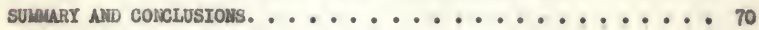

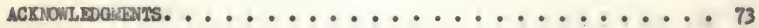

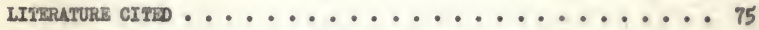
APPENDIX

I. Procedure for Blood Volume Determination ........ 92

II. Calculations for the I-1824 Wethod .......... 96 III. Calculationa for the P-32 Hethod ........... 98

IV. Procedure for Red Blood Cell Count ........... 99

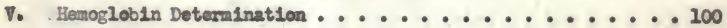

vI. Apparatus Used in the Syringe Method .......... 102

VII. Reagents Used in the Syringe Method. . . . . . . . 102 VIII. Procedure with the Syringe Nethod........... IOl

IX. Callevlations of Oxgren Capacity with the Syringe Method. . 208 BICORAPHY. . . . . . . . . . . . . . . . 109 


\section{INMRODUCTION}

While considerable research reported in the iltarature deals Wh changes in total blood volume associated with pethological condit1ons in man, relatively l1ttle information 18 avallable with regard to the total blood volume of normal laboratory and wild aninals. Changes in total blood volume in varicus mamala have been reported in regard to ecology, diet, hemorrhage, psychosomatic conditions, and other disturbances.

In studies made at sea level and at altitudes above 11,000 feet, Santh et al. $(1924-25)$ reported a 12 per cant increase w1 th increased altitude in the red blood cells of $3 i x$ men. This was based on a change In the mean total blood volume fron 4484 to 5063 cublo centimeters as determined by the carbon monoxide method which 1 described later. However, with the dye method, also to be described later, the invest1gators reported an unexplained decrease from 6187 to 6071 cublo centimeters.

On prolonged exposure to a high onvironmental tenperature blood volume tends to inorease and to decrease in colder temperatures accordIng to Bazett ot al. (1940). Mitchell (1938) reports that temperature regulation in mamals at enviromental temperatures fron about 15 to 37 degrees centigrade is effected almost entirely by control of the rate of heat 10as. Barbour (1921) has shown that a fundanental factor, in which temperature contral is necesaltated by regulation of heat loss, is the change in the water content of the blood. This movement of water 
is reflected by a change in blood valune, and with an inerease in blood volune, there may be a marked increase in secretion of sweat. By means of this movenent, water, the chief heat transporter of the body, is retained in the t1ssues in Inoreasing amounts during exposure to cold, but is freed to convey heat to the radiating surfaces of the body during exposure to heat (1ititchell, 1938).

In a study of diuresis in dogs, Evans and Gobson (1937) report that the blood volune decreases "proportionally with the angitude of the diuresia."

That acute and chronic dehydration produced experimentally in dogs results in a 15 to 30 per cent reduction in plasma volume is reported by Gibson (1941).

There is a 9.3 per cent 100 of blood volume in man after a bed reat of three weeks, according to Taylor et al. (1945).

In etudies on soldiers of World War I, Robertson and Bock (1919) report that in cocudation of wounds the total blood valume was sometines Lowered as much as 2000 cublc oentimeters.

"The anount of blood which an be added to the general circulation of eats by contraction of the spleen upon stimulation of the eplanchnic nerves is of the order of 2.6-5 p.c. of the total blood volume of the animal," according to Crulckshank (1926).

An increase in erythrocytes in the blood of wan 1s reported to be accoupanied by a deorease in the circulating plasma by Brednow (1931). During exotional excitenent in rabbits, there is reported to be a 20.2 per cent increase in the red cell volume and a decrease of 8.5 
per cent in plasma volume; in the 11 aninals repartod on by lice and Kata (1934), there was a rise of 1.7 per cent of the total blood rolume during the enotional excitement.

In cobalt polycythemia, the blood volume rises from 6.38 to 7.89 cuble centineters per 100 grams of body weight according to Orten et 으. (1933). Davls (1940) reports a 17 to 22 per cent greater blood valume in dogs in cobalt polyeythenia. In theix studies on rats in cobalt polyoythemia, Stanley et al. (1946) report that blood volumo Increased 80 per cent.

"Much of our information with regard to the blood volume and Its regulation has come to us through efforts that have been made to develop methods, and often this information is colored by the individual mothod through which 1t has been derived," Exlanger (1921). In the following discussion, the various methods are growped sccording to their underlying principles.

Bleeding Method

A direct method of blood volume determination was described by Weloker (1858). He took a gmall measured sample of blood from the animal and diluted it 1:100 in saline solution. The animal was then bled, the blood ressels washed out with water, and the tissues mascerated. Water was then added to the collected nuid until Its color matched the color of the original blood sample. The total collected fluid divided by 100 gave the total blood volume of the animal. Obvlously, this method is not free from serious error. The turbidity of the final solution 
prevents exact color matching, the myoglobin of the muscles cannot be distinguished from the hemoglobin, and the loss of hemoglobin as a result of intravascular and extravascular clotting leads to further error. Despite these inaccuracies of the bleeding method, maxy investigators have used it as may be seen from Tablo VI..

\section{Indirect Methods}

\section{Obsolete Methods}

The first method for determining the total blood volume in an animal was deseribed by Valentin (1838). He states that a sample of blood was withdrawn and the percentage of solids was determined. Then a known volume of distilled water was infected intravenously. After a measured time interval, a second sanple of blood was withdrawn and the percentage of solids detemined. A conparison of the percentage of solids of the two samples was interpreted as an Indication of the anount of dilution of the blood caused by the injection of distilled water. From these data the total blood volume was determined. The use of distilled water was objectlonable because hemolysis occurred, and a solution of sodiua chlorlde came to be used Insteed.

Sherrington and Copemen (1893) diluted the blood: with 0.75 per cent sodiun chloride. They withdrew about one-third of the blood from a rabbit and injected the amount of sodium chloride solution within 15 seconds. They determined the total blood volume by the degree of dilution on a withdrawn sample which was taken 30 seconds later. The apecifio gravity was used as an Index. Kottman (1906) deterndined the total blood volume in man by means of the sodium chloride method. He 
injected 3.5 cubic centineters of isotonle alt solution per klogran of body weight and determined the dilution by means of a homatocrit value obtained before and after injection. Plesh (1909), also working with man, injected a larger quantity of sodiun chloride solution, 5.0 cuble eentineters per kdlogran of body welght, and ealculated the total blood volume from the dilution value whlch was deternined by means of a Plesh colorineter.

Subatances other than sodium chloride have been used in attempts to detemine total blood valume. Helson (1909) reports the reaults (see Table VI) found in rabbits when an animal is bled first and the amount of blood lost is replaced by an equal amount of serum as suggested by Halassez (1875). Von Berlng (1911) used "antitoxdn and the dllution was deternined bialogieally." Schurer (1911) injected foreign serun and studied Ita dilution quantitatively by precipitin reactians. Heek and Gasser (1918-19) used gun acacis as an Intrevenously injected colloid, and determined gravimetrically at the and of three mimates the anount of Bun acacia in a known volune of blood. Robertson and Boek (1919) Injected a 6 per cent salution of gum acadia in physiological saline solutions and determined the total blood rolume by using the henoglobin dilution as an Index. Mopuarrie and Davls (1920) Injeoted a "non-coagulable, highly reIractive substance, gum acacia and golatin solution," and noted the change in the refractive index as the reault of the dilution. Lee and Whipple (1921) Injected hemoglobin to messure the plasms volume which served as a measure of the total blood volune.

The aarbon monoxide method for detormination of total blood 
volume was introduced by Grehant and Quinquand (1882). Woriding with dogs, they allowed the animal to breathe a known amount of carbon monox1de from a bag. Then they determined gasconetrically the anount of earbon monoxide in a withdram sample of blood. This amount was then compared with a standard in which a knom anount of carbon monoxide was combined with a knom rolune of blood. The dilution served as a measure of the total blood volune. Haldane and Smith (1899-1900) adapted this method to the determination of total blood rolume in man. Since the publication of their results, wany investigators have used the carbon monoxide method to study total blood volume in different species as shown in Table VI. Blood volume for supposedly norwal manals are given In this table pollowing the elassification by Simpson (1945).

The disadvantages of the carbon monoxide method have been pointed out by Reeve (1948) who states, "Th1s is one of the oldest and most critleised of the more precise methods." Among the diffloulties is the socurate determination of earbon monoxdde by gasonetric and colorimetric methods, and the amount of carbon monoxide diffusing into the tissues fron the blood.

Dre Yethods

The dye method for blood volume investigation was flrst introduced by Keith et 르. (1915) of Johns Hoplding Univeraity. In looking for a non-texic dye that reasalned in the blood long onough for thorough mixing, one that was absorbed but little, and one whose concentration could be deternined colorimetrically, these workers had the dre, Vital red, suggested to then by Dr. Herbert M. Evans of the Anstauical Department 
of the Johns Hopkins Hospital Staff. When Dr. Evan later became Professor of Anatony at the Umiveraity of Callfornla, Hooper 트 르. (1920) of the University of Callfornia asked Dr. Evans to suggest another dre that night possibly be used for total blood volume deternination since the dre, vital red, was not avallable. He suggested the dre, brilliant vital red, which these investigators used In a study on dogs.

In view of the Increading interest in the dye method among rosearch workers investigating blood volwae in animals, Dawsen et a․ (1920) belleved 1t desirable to study many dye substances which might be of value for future workers.

Sixty-one dyes were divlded into three groups for evaluation by studies on dogs. Croup I contained 30 dyes reseabling the vital red serles In that they persist in the blood plasma. Croup II contained I4 dyes which leave the blood strean rapldiy and appear in the urine. Croup III centalned 17 dyes which leave the blood strean rapidly, but do not appear to any degree in the urine. The dyes were evaluated for possible exrors in calorinetry, mixing time, time of dissppearance rrom the blood, teaciclty, and arallability.

Studies of Congo red and vital red in doge and cats to determine which of these two dyes is more suitable for clinieal use are reported by Harris (1920). He found that Congo red 18 better sulted for color aetric studies since the rate of disappearance of v1tal red is about 12 per cent greater over a 30 mimute period. Craff and clarke (1931), In calorimotric studies of briJliant vital red, denonstrated that hemolysis sometines occurs in which case the hemoglobin 11berated makes calor 
matching unreliable.

The prineiple that solutions of different compound possess char acteristic absorption spectra which may be readily detseted by spectrogcopy was used by Gregersen et a․ (1935). They reported that the maximum absorption range for $T-1824$ (Evans blue) dye was 620 to 630 m1111mierons as deternined with a spectrophotaneter. They state that there is practically no absorption of light by hemoglobin (which has a maximum absorption range of 5 l4h to 576 millidiorons) if henolysis occurs in the blood sanple in the absorption range of the T-1824 dye. Hewever, since the absorption range for the $\mathrm{V}$ tal red dyes (about 520 millimocrons) is eloser to the absorption range for hemoglobln, hemolyais would result in error. The T-1824 dye has subsequently becone the accepted dye for blood volune Investigations.

The T-1824 dye exhibited no toxle effects on wale rats when 1 t was injected 1ntravenously in doses of 20 milligrans per k1logran of body weight (Gibson and Gregersen, 1935). Oibson and Bvans (1937) adopted the method utilising the T-1824 dye as a clinical means of determining total blood volune in man.

In a study of the absorption curve of the T-1824 dye, Gibson and Bvelym (1938) introduced the use of a photoelectric colorineter for measuring the optical density of the dye wlth a fllter having a maxdmun transmittancy of 11ght in the range of 620 to 625 millinicrons. The amount of various dres absorbed by red blood cells has been studied by different investigators. Cregersen and Sohiro (1938) state that $\mathrm{T}-1824$ dye is not absorbed by the red blood cells in dog blood. 
Shohl and llunter (19/4) report this is also true for hunan red blood cells. Indhard (1926) reports that vital red is absorbed by the red blood cells of an cx, less by the red blood cells of a dog, and no absorption eccurs by the red blood cells of man. Ilowntres et 르. (1929) report that Congo red and vital red do not enter the red blood cells of nan.

Ferrebee et al. (1941) report that a trace of $\mathrm{I}-1824$ dye passes Into the lymph In dogs chring the flrot 30 to 60 minutes following the time of injection. However, they state that this anount is not "oritically significant" in the evaluation of the accuracy of the dye for blood volume deternination.

Substances used in blood valune deteminations such as sodium chloride, antitodin, hemoglobin, serum, Ringers solution, and acacla do not give accurate resul to because of thedr rapld diffualon fron the blood, as potnted out by Erlanger (1921). Radiasotive Methods

The Irst successful attengt to determine total blood valume by the use of radioactive phosphorus was made by Hahn and Hevesy (1940). They injected a knom volune of labelled red blood cells taken fron a donor rabbit into the vein of a reciplent rabbit. Then they ealeulated the total blood volume by deteraining the extent to whlch the labelled corpuacles were diluted in a sample taken 5 mimutes later. The labelled red blood cells were prepared by injeoting the donor rabblt subcutaneously wth radiosctive sodiun phosphate over a period of a week. This procedure allowed the red blood cells to incorporate some of the labelled 
phosphatide molecules. Hahn et al. (1941) followed the method of Hahn and Hevesy (1940) in the preparation of donor red blood cells to infeet Into a recipient animal except that they used radioiron in dogs. Anderson (1942) and Hevesy and Zerahn (1942) studied total blood valume and red cell volune, respeotively, in rabbits using radioective phosphorus. Red blood cells ware labelled in itro, washed with physiological saline solution, and injected into the animal. The radiosctivity of a sample of Labelled, wthdrawn blood was compared with a standard ade from the infection solution. This served as measure of the dilution volume in the aninal. Govaerts (1942), in studying total blood rolume in man and dogs, used the method of Hahn and Hevesy (1940).

A radloative isotope of lodine (I-131) for dotermining total blood volume was Ilrat used by Fine and Seligman (1943). This work was done to evaluate the total volume of blood in man. In this method the protein fraction of plasm is labelled with I-131. A solution containing potassium iodice plus the carrier-free I-231 and nitrie acid was distilled into cold distilled carbon tetrachloride. The carbon tetrechloride solution of lodine was washed with distilled water and added to chilled plasma which was prevlously extracted with carbon tetrachlorido. Sodium carbonate was added and the mixture shaken until the color disappeared. The plasma was separated by centrifugation and then dialyzed for 48 hours against cold runing water. The precipitated globulin was centrifuged and the supernatant plasme wes ready for use.

The technique of Hevesy and Zerahn (1942) for the deterndnation of total red cell volume was modified by Hevesy et 르. (1943-444). "A 
part of the blood ample containing labelled corpuseles is reintroduced Into the circulation. After the lapse of about 5 minutes, a blood sample Is secured and the radicactivity of the corpuscles of this sanple is conpared with the radioativity of the reintroduced corpuseles of equal weight. The ratio of the radiosctivity of the two samples is a moasure of the amount of corpuscles present in the circulation."

Nylin (1945) exployed the methods of Hahn and Hevesy (1940) and Hevesy and Zerahn (1942) in alinical Investigations of total blood volume in man.

A comparative study in dogs was made by Krleger et 르 (1948), using the methods described by Hevesy and Zerahn (1942) and Fine and Seligman (1943). Nachman et 르. (1950) also used radioactive phosphorus to label the red blood cells of man fallowing the methods described by Hevesy and Zerahn (1942) and Anderson (1942). Talow and Berson (1951) used radiosctive potassium $(\mathrm{K}-42)$ to label red blood cells in V1tro. They followed Reeve and Veall (1949), who used the methods of Anderson (1942) and Hevesy and Zerahn (1942) with radiosctive phosphorus in man. 


\section{METHODS AND MATERIALS USED IN THE PRESENT INVESTIOATION}

Two methods of blood valume investigation were followed in the present studj. In one method radioactive phosphorus-32 (P-32), which was incorporated in phosphorle acld $\left(\mathrm{B}_{3} \mathrm{PQ}\right)$, was used. In the other method, T-1824 (Bvans blue) dye was used. A cardise punoture was made on the animal and a sample of blood withdrawn by means of a needle and syringe coated with heparin. The blood was centrifuged in a No. 2 International centrifuge at $3000 \mathrm{rpm}$. for 30 ninutes. The plasma was renoved with care so as not to disturb the red blood cells. The red blood cells were washed 3 times with 1ced, physiologlcal aeline solution and centrifuged sfter each washing at $3000 \mathrm{mpm}$. for 5 minutes. A volume of 1sotonic P-32 solution, which contained approximately 50 wierocurles of radioactive phosphorus, ws added to the red blood cells. The solution added was equal to the volune of plasma ortofinally present in the withdram blood sample. The red blood cells were inoubated in this solution In a water bath at 37 degrees cent1grade for two hours. About evary ten or. Ifteen alnutes the suspension was stirred with a small, glass rod. At the end of the labelling period, the radloactive solution was centrifuged at $3000 \mathrm{rpm}$. for 5 mimutes. The red blood cells were again washed 3 tines with physiological saline and centrifuged after each washIng at 3000 rga. for 5 minutes. After each washing, the supermatant was pulled off by a suction pipette so as not to disturb the red blood cells. Ioed, phyriological saline solution was added to the red blood cells ao that the resulting mixture was equal to the original rolune of blood 
withdrawn from the enimal. The mixture was then stirred manually with a small, class rod and an al lquot was taken for a standard which was made to a defint te voluae. A known velume of the labelled red blood cell solution was stored in a syringe until it was injected into the Jugular vein of the animal. This procedure is essentially the ame as that described by Hevesy et aㅡ. (1943-44h) and modifled by Jwohnan eㅡ al. (1950).

A standard and a blank sample for the dye method were prepared during the two hour time interval of labelling the red blood cells. A solution was prepared by diluting a known concentration of $\mathrm{T}-1824$ dye to a derinite volume with physiological saline solution. An aliquot of this dye solution was then diluted to a known volume with distilled water. A known volume of the diluted dye solution was then added to a known volume of plasma. The nixture served as the standard solution. The plasea proteins were precipitated by alcoholio phosphotungstio acid solution, a procedure described by Crooke and llorris (1942) for the prevention of turbldity in plasma samples. Precipitation was allowed to occur in the plasma sample for 5 minutes while it was being stirred with a sall, Elass rod. The suspension was then oentrifuged for 5 mimtes at $3000 \mathrm{rpm}$. The optical density of the standard solution was read on a Rett-Sumerson photoelectric colorimeter by use of a filter with a maxImam transaission of light at 622.5 millimierons. The filter, as sold by the A. H. Thomas Co., Philadelphis, is their Gatalog No. 3788-03. The colorimeter was zeroed by the use of the blank sauple which was prepared in the same manner as the otandard except that the dye was 
anitted. The procedure outlined above follows that of Gregersen (1944). A known volume of the dye in saline solution was stored in a eyringe until it was injected into the blood of the animal.

An aninal was tied to an animal board in a supine position and etherized. An inciston was made over each Jugular vein after the area had been elipped to free It from interfering hatrs. Alcohol was rubbed on the skin and the jugular vein was then exposed and freed from the connective tissue surrounding 1t. A probe was placed under the vein to facllitate insertion of the needle. The needle of the syringe containIng the P-32 or the I-182h dye solutions, or both, was inserted Into the veln and the injeotion was made wi th the point of the needle difected toward the heart. After the solutions were injected, the syringe was flushed two or three times with blood in order to Insure the introduction of all of the dyo and cell solution into the blood. The needle was quickIf renoved and the wound pressed with an absorbent eloth. After a derInite time interval, a blood sample was withdrawn from the opposite jugular voln into a syringe which had a drled coating of herapin in it. In this withdrawal of blood, the needle on the syringe was pointed toward the head. The withdram blood was deposited in a centrifuge tube containing a definite anount of heparin solution. The ample of blood was then centrifuged for 30 alnutes at 3000 rpun.

The plasma was separated from the red blood colls and the hematoarit value recorded. I definite valuae of the plasme was treated in the same manner as the blank and the standard, and the optical density deterulined by means of a photoelectric colorimeter. The total plasma 
valume and the total blood valume were calculated fren the formulas shown on pages 96 and 97 (Appendix II).

The red blood cells of the withdram sanple were washed 3 times with physiologteal saline and centriluged at 3000 rpas. for 5 alinutea after each washing. The cells were dluted to a definite valune with distilled water. The radiosctivity of this solution and of the standard was then determined. This was accouplished by taking an aliquot of the sample solution and counting the activity on a comereial scaler. In this Investigation, two counters were used; one was an Autoscaler manufactured by Traeer labs., Inc., and the other was a Cyolotron from the Cyclotron Specialties Ccoppany. Both scalers were used in conjunction with an immerslon-type Oelger Muller tube. Data for corrections of background count fram cosmic radiation were made at the beginning of each activity count. From these data the total blood volune was calevlated according to the formula shom on page 98 (Appendix III).

Red blood cell counts and hemoglobin coneentration were made for each animal. The red blood cells were counted according to the method described by Kolmer and Boerner (1945) and the hemoglobin was deternined by the acid heastin method on a FIsher electro-hemoneter. The procedures for each wethod are given in Appendices IV and V.

A detailed description of the procedure for the deternination of blood volume by the $\mathrm{P}-32$ and $\mathrm{T}-182 \mathrm{~h}$ dye methods which was followed in this Investigation is Given in Appendix I. 


\section{INVESTTCATIONS OF OPOSSUNAS}

The opossun, Didel phis virginiana pigra (Bangs), served as a corvenient animal for blood volune investigations. Twenty-four specimens were trapped or eaptured in the wild atate from September, 1950, to DEcenber, 1951, during which tine the blood volume of these animals was invest1gated.

\section{Blood Volune Determinations with}

$\mathrm{T}-1824 \mathrm{D}$ De and $\mathrm{P}-32$

Blood volume deterninations were made on 10 opossuns using I-182h dye and radiosctive phosphorus-32. Dats concerning these animals are Given In Table I. It is notewarthy that the values for the total plases volume, total red cell volume, and total blood volume is higher in the dye method than in the P-32 method by mean values of $5.8,4.0$, and 9.9 mi., respectively.

The mean value plus or mimus three times the standard devlation gives the theoretical 1 indts found in 99.7 per cent of the population according to Slapson and Roe (1939). For the dye method these values are 8.32 to $3.34 \mathrm{ml}$. and for the P-32 method they are 7.65 to $3.33 \mathrm{ml}$. of blood per $100 \mathrm{gme}$ of body wedght.

The relationship of the ml. of blood per $200 \mathrm{gm}$. of body weight of the 10 opossums studied by the T-1824 dye and P-32 methods 1 s shown In Graph I. This shows that there 18 a decrease in the anount of blood per 100 gin. of body wolght with an increase of body weight. The lines of trend were deternined for each method by the method of least squares 


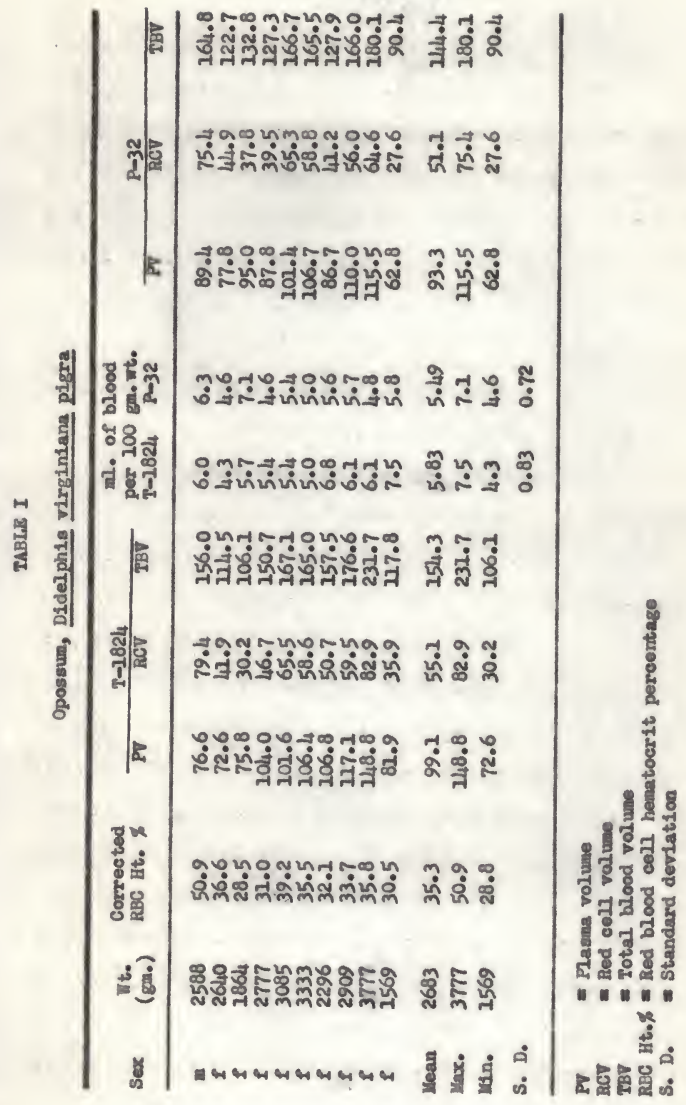


(SImpson and Roe, 1939). The coefficients of correlation deternined for the dye and P-32 methods were 36.36 and 35.88 per cent, respectively. Blood volune was deternitned by the P-32 method in 4 opossume in addition to the 10 animals listed in Table II. Two of the animals were fomales of 2105 and 1750 grams of body weight with 6.3 and $6.7 \mathrm{ml}$. of blood per $100 \mathrm{gm}$. of body weight, respectively. The other two were males of 2505 and $2050 \mathrm{gz}$. of body welght with a blood volume of 8.0 and $7.5 \mathrm{ml}$. per $100 \mathrm{gm}$. of body welght, respectively. A standard devlation of $1.1 \mathrm{ml}$. of blood per $100 \mathrm{gm}$. of body wolght was found for the If animals whose average welght was 2517 grams. The mean blood volume in these animals was $5.86 \mathrm{ml}$. of blood per $100 \mathrm{gm}$. of body weight. Craph II shows the relationship of millilliters of blood per $100 \mathrm{gm}$, of body weight to an increase in body weight for these animals. The line of trend was determined by the method of least squares as mentioned above. The coeffleient of correlation for the 14 animals was 39.19 per cent.

\section{Hiding Time and Rate of Disappearance of Dye and P-32}

In addition to the blood volume deterninations made on the opossums mentioned above, the mixing time and rate of disappearance of the T-182h dye and the red blood eells labelled wth radioective phosphorus in the blood of the opossum was studied. In 7 of the animals listed in Table II blood semples were withdrawn at $1,3,5$, and 10 inimites after injection of the dye and labelled cell solution. On Graph III is shown 
the calculsted blood volume in alliliters of blood per 100 grams of body weight plotted against time in mimutes for the dye method. The points plotted represent the average figure for the 7 animals as calculated for each unt of thme. There is a difference of $0.3 \mathrm{ml}$. of blood per 100 grams of body weight from the 1 to the 10 minute period according to these determinations. Mis indicates that the dye has become sufficiently well mixed in the blood so that a ralid estination of blood volume may be made on any sample withdrawn 1 to 10 airutes after Infection of the $\mathrm{T}-1824$ dye.

Data for the P-32 labelled cells of the 7 opossums used are presented in Oraph IV. Here there is a difference of $=0.4 \mathrm{ml}$. of blood per 100 gile of body welght over the 1 to 10 minute sampling per1a. This insignifleant variation 18 also an indication that the labelled red blood cells have been sufflatently well mixed by 1 int nute so that a valid estination of blood rolume nay be made on any sample withdrawn between the 1 and 10 minute period after injection.

Data for blood volune of the opossums used are presented in Table II. These data are shown on Craph $V$ whero the lines of trend. were determined by the method of lesst squares. The coeffleients of correlation for the T-1824 dye and P-32 methods in the 7 opossums are 34.86 and 44.35 per cent, respectively... The coefflelent of variation (In Table II) was deternined using the method of S1mpson and Roe. From a statistical treatment of the ignifleance of differences between the coefficients of variation for each method, it was found that the $n_{t}$ value is 2.2. Since this "tn value is only on the borderline of 


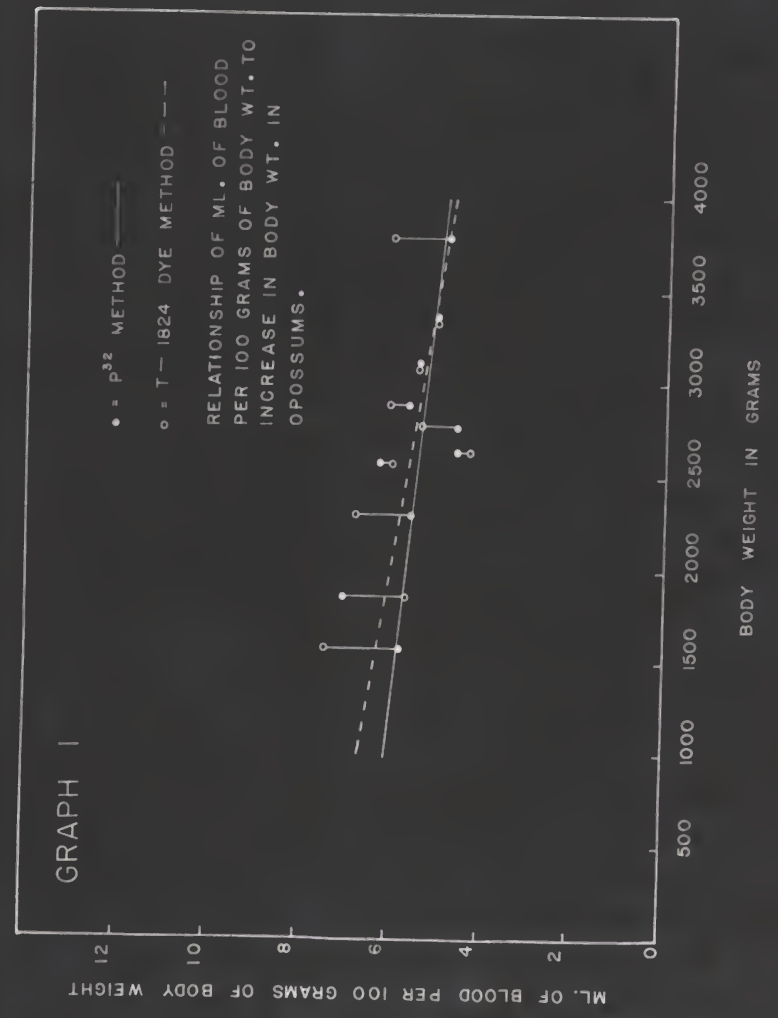




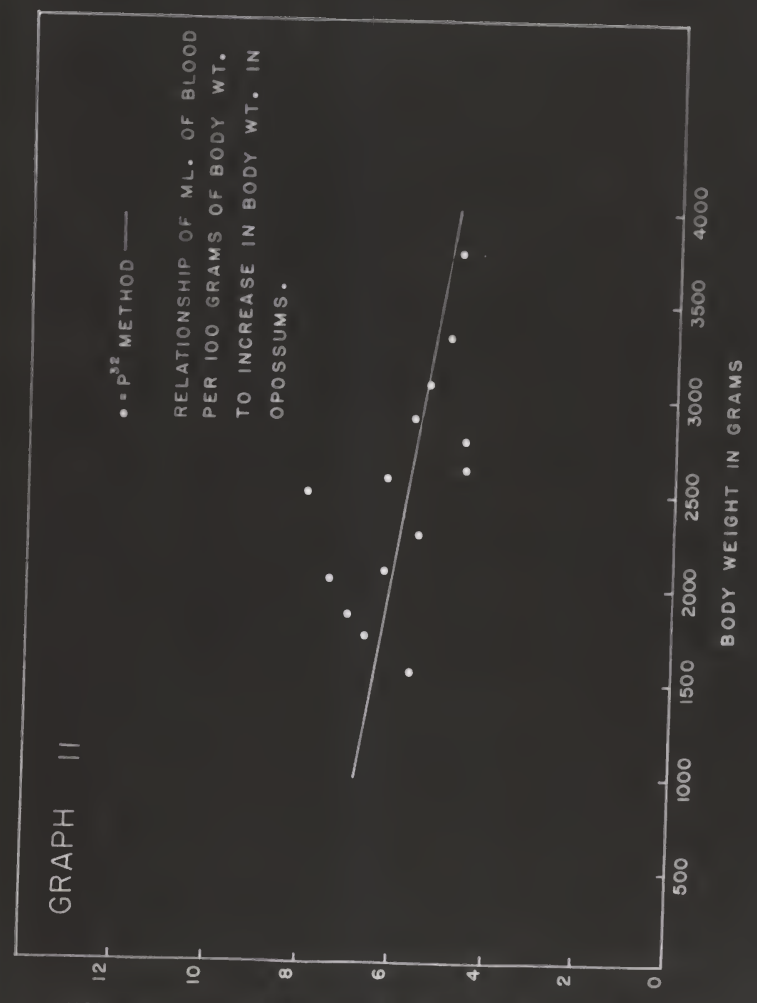

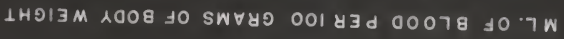




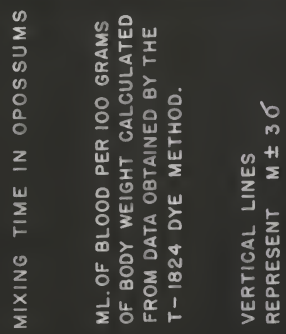

$=$
$\frac{1}{\alpha}$
$\frac{1}{0}$ 
signifleance, neither method can be expected to give a more correct blood volume Ilgure than the other.

The mixing time of substances in the blocd of other species has been 1nvest1gated by other workers. The mixdng time using $\mathrm{T}-182 \mathrm{~h}$ dye, in man, is 6 ainutes according to C1bson (1937) and Less than 20 minutes according to Campbell et 르. (1948). Robinow (1940) reports that the mluding time for brilliant vital red in man 18 greater than 1 minute. In the dog, using I-1824 dye, G11der et aㅡ. (1940) report a mixdng time of less than 5 mimitess Miller (2947) reports 4 to 6 minutess and Lawson et 르. (2947) report 3 to 5 minutes. Nlso in dogs, Hahn et al. (1941) report a mixing time with radiodron of less than 20 mimutess Gallhorn eㅡ aㅡ. (1944), using radioiron, report 4 minutes as boling sufflelent for alxing. Hahn et aㅡ. (1940) report a $2 \frac{1}{2}$ minute mixing time In a rabbit for P-32. Crulckshank (1945), in using $\mathrm{T}-1824$ dye, reporto that more than 1 aimite is necessary for mixding in the oat.

The disappearance rate of the $\mathrm{I}-1824$ dye and P-32 labelled cells was studied by the author in the blood of an opossun which weighed 2777 gramb. These data are presented in Craph VI. The per cent dre decreased from 79.8 per cent at 1 hour to 33.6 per cent at 6 hours, 11.2 per cent at 28 hours, 7.2 per cent at 24,4 hours, and at the end of 48 hours there was no dye present in the blood. At the end of the first hour after injection of the labelled red blood cells, which at one minute had an act1v1ty of 2420 counte per mimite per ml., 80.8 per cent remasned, at 6 hours 55.9 per cent, at 18 hours 36.3 per cent, at 24 hours 29.5 per cent, 


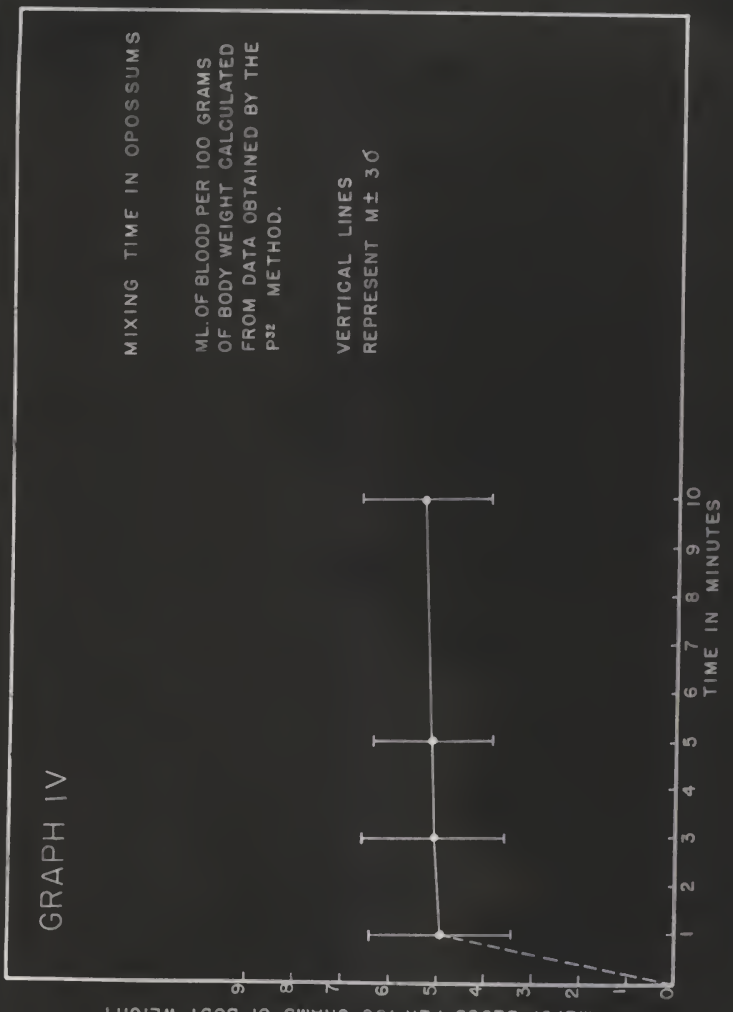

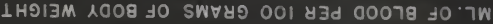




\title{
TABLE II
}

\begin{abstract}
Opossun, Didelphis virginiana plexa
Blood valume in ml. per $100 \mathrm{gm}$. of Body We1 ght in Relation to Mixing Time
\end{abstract}

\begin{tabular}{|c|c|c|c|c|c|c|}
\hline \multirow[b]{2}{*}{ Werght } & \multirow[b]{2}{*}{ Nethods } & \multicolumn{4}{|c|}{ u 1 n x $t$} & \multirow{2}{*}{ Average } \\
\hline & & 1 & 3 & 5 & 10 & \\
\hline 2777 & $\begin{array}{l}p-32 \\
T-1824\end{array}$ & $\begin{array}{l}4.27 \\
5.29\end{array}$ & $\begin{array}{l}4.58 \\
5.43\end{array}$ & $\begin{array}{l}4.45 \\
5.35\end{array}$ & $\begin{array}{l}4.87 \\
5.43\end{array}$ & $\begin{array}{l}4.54 \\
5.37\end{array}$ \\
\hline 3085 & $\begin{array}{l}P-32 \\
T-1824\end{array}$ & $\begin{array}{l}5.59 \\
5.55\end{array}$ & $\begin{array}{l}5.45 \\
5.60\end{array}$ & $\begin{array}{l}5.40 \\
5.42\end{array}$ & $\begin{array}{l}5.72 \\
5.63\end{array}$ & $\begin{array}{l}5.54 \\
5.55\end{array}$ \\
\hline 3333 & $\begin{array}{l}P-32 \\
T-1824\end{array}$ & $\begin{array}{l}4.93 \\
5.02\end{array}$ & $\begin{array}{l}4.82 \\
5.08\end{array}$ & $\begin{array}{l}4.96 \\
4.95\end{array}$ & $\begin{array}{l}5.09 \\
5.33\end{array}$ & $\begin{array}{l}4.95 \\
5.09\end{array}$ \\
\hline 2296 & $\begin{array}{l}P-32 \\
T-2824\end{array}$ & $\begin{array}{l}5.10 \\
6.35\end{array}$ & $\begin{array}{l}5.57 \\
6.85\end{array}$ & $\begin{array}{l}5.28 \\
6.80\end{array}$ & $\begin{array}{l}5.58 \\
6.99\end{array}$ & $\begin{array}{l}5.38 \\
6.75\end{array}$ \\
\hline 2909 & $\begin{array}{l}p-32 \\
2-1824\end{array}$ & $\begin{array}{l}5.25 \\
5.85\end{array}$ & $\begin{array}{l}5.70 \\
6.07\end{array}$ & $\begin{array}{l}5.48 \\
6.09\end{array}$ & $\begin{array}{l}5.47 \\
6.30\end{array}$ & $\begin{array}{l}5.47 \\
6.07\end{array}$ \\
\hline 3777 & $\begin{array}{l}\mathrm{P}-32 \\
\mathrm{~T}-1824\end{array}$ & $\begin{array}{l}4.15 \\
5.93\end{array}$ & $\begin{array}{l}4.28 \\
6.04\end{array}$ & $\begin{array}{l}4.76 \\
6.32\end{array}$ & $\begin{array}{l}4.81 \\
6.20\end{array}$ & $\begin{array}{l}4.50 \\
6.07\end{array}$ \\
\hline 1569 & $\begin{array}{l}P=32 \\
T-1824\end{array}$ & $\begin{array}{l}5.29 \\
7.44\end{array}$ & $\begin{array}{l}5.52 \\
7.52\end{array}$ & $\begin{array}{l}5.76 \\
7.50\end{array}$ & $\begin{array}{l}6.15 \\
7.56\end{array}$ & $\begin{array}{l}5.68 \\
7.50\end{array}$ \\
\hline Hean & $\begin{array}{l}P-32 \\
T-1824\end{array}$ & $\begin{array}{l}4.94 \\
5.92\end{array}$ & $\begin{array}{l}5.13 \\
6.08\end{array}$ & $\begin{array}{l}5.15 \\
6.06\end{array}$ & $\begin{array}{l}5.38 \\
6.20\end{array}$ & $\begin{array}{l}5.15 \\
6.05\end{array}$ \\
\hline S. D. & $\begin{array}{l}P=32 \\
T=1824\end{array}$ & $\begin{array}{l}0.49 \\
0.74\end{array}$ & $\begin{array}{l}0.50 \\
0.78\end{array}$ & $\begin{array}{l}0.42 \\
0.82\end{array}$ & $\begin{array}{l}0.46 \\
0.77\end{array}$ & $\begin{array}{l}0.45 \\
0.77\end{array}$ \\
\hline , & $\begin{array}{l}p-32 \\
x=1824\end{array}$ & $\begin{array}{l}0.099 \\
0.125\end{array}$ & $\begin{array}{l}0.097 \\
0.128\end{array}$ & $\begin{array}{l}0.081 \\
0.135\end{array}$ & $\begin{array}{l}0.085 \\
0.224\end{array}$ & $\begin{array}{l}0.087 \\
0.120\end{array}$ \\
\hline Mascinnan & $\begin{array}{l}P-32 \\
T-1824\end{array}$ & $\begin{array}{l}5.93 \\
7.44\end{array}$ & $\begin{array}{l}5.70 \\
7.52\end{array}$ & $\begin{array}{l}5.76 \\
7.50\end{array}$ & $\begin{array}{l}6.15 \\
7.56\end{array}$ & $\begin{array}{l}5.68 \\
7.50\end{array}$ \\
\hline Hentaran & $\begin{array}{l}p-32 \\
p-1824\end{array}$ & $\begin{array}{l}4.15 \\
5.02\end{array}$ & $\begin{array}{l}4.28 \\
5.08\end{array}$ & $\begin{array}{l}4.45 \\
4.95\end{array}$ & $\begin{array}{l}4.81 \\
5.33\end{array}$ & $\begin{array}{l}4.50 \\
5.09\end{array}$ \\
\hline$\mu+3 \sigma$ & $\begin{array}{l}P=32 \\
T-1824\end{array}$ & $\begin{array}{l}6.41 \\
8.23\end{array}$ & $\begin{array}{l}6.63 \\
8.42\end{array}$ & $\begin{array}{l}6.41 \\
8.52\end{array}$ & $\begin{array}{l}6.76 \\
8.51\end{array}$ & $\begin{array}{l}6.50 \\
8.36\end{array}$ \\
\hline$M-3 \sigma$ & $\begin{array}{l}P-32 \\
T-1824\end{array}$ & $\begin{array}{l}3.47 \\
3.69\end{array}$ & $\begin{array}{l}3.63 \\
3.74\end{array}$ & $\begin{array}{l}3.89 \\
3.60\end{array}$ & $\begin{array}{l}4.00 \\
3.89\end{array}$ & $\begin{array}{l}3.80 \\
3.74\end{array}$ \\
\hline
\end{tabular}




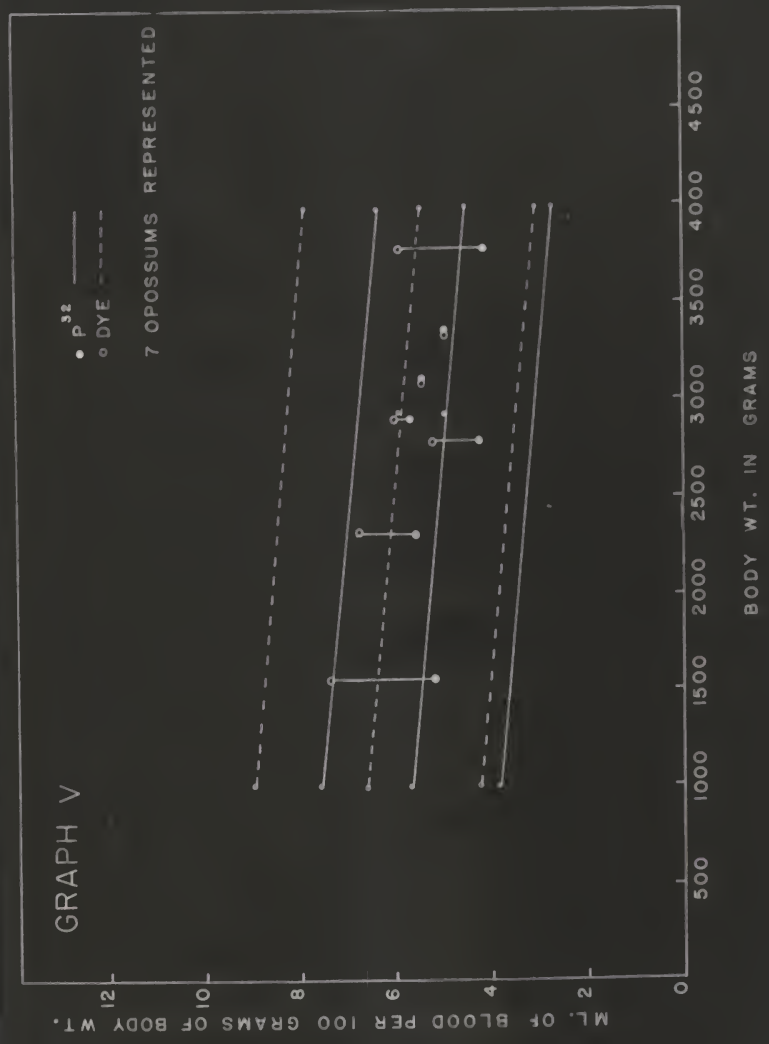




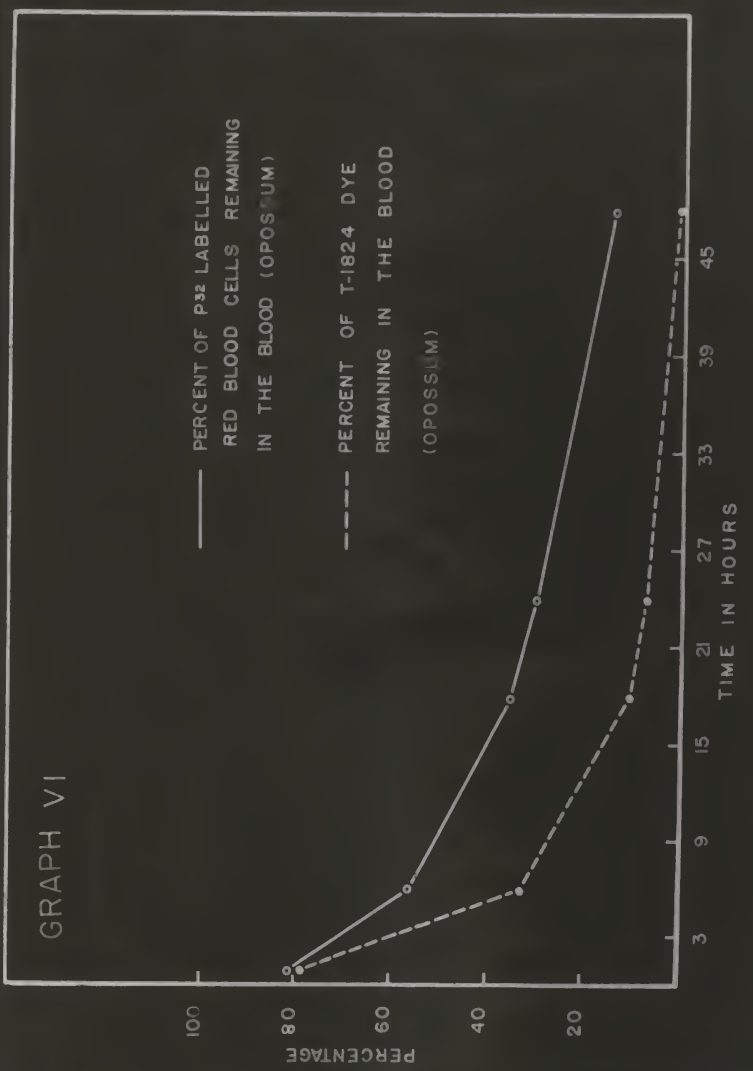


and at 48 hours 13.8 per cent remained in the blood.

Uptake by Red Blood Cells of P-32

The percentage uptake of radioaotive phosphorus-32 by the red blood cells of an opossum was also studied. These data are presented in Graph VII. Twenty milliliters of blood were withdrawn from an opossum by a cardiac puneture into a heparinised syringe. The blood was centrifuged at 3000 rpm. for 30 mimutes. The plasma was discarded and the cells were mashed with iced, physiological, saline solution and centrifuged 3 times at 3000 rpm. for 5 minutes. These red blood cells were then made to the original voluae of blood withdramn from the animal Wh theysiologioal ealine solution. One milliliter of isotonie radioaotive sodium phosphate was diluted with distilled water to make a rolume of $250 \mathrm{ml}$ used as a standard. Then the radiosctive sodiun phosphate solution was added to an equal volume of the washed red blood cell solution. Six ml. of this mixture was placed in each of 5 centrifuge tubes which were then placed in a water bath of 37 degrees centigrade. Bvary few minutes the solutions wore stirred with small, glass rods. At 5 and 30 mimutes and at 1,2 , and 3 hours a tube was renoved, the cells washod 3 times with leed physiological saline, and contrifuged for 5 minutes at $3000 \mathrm{rpan}$. after each washing. The labelled cells were made up to 500 mil. and counted on a Gelger counter as desaribed in Appendix I. A cosparison of the activity of the standard with the activity of the sample Indicates the amount of P-32 taken up by the red blood cells. If the standard be assumed as 100 per cent there was 11.2 per cent radiosctivity 


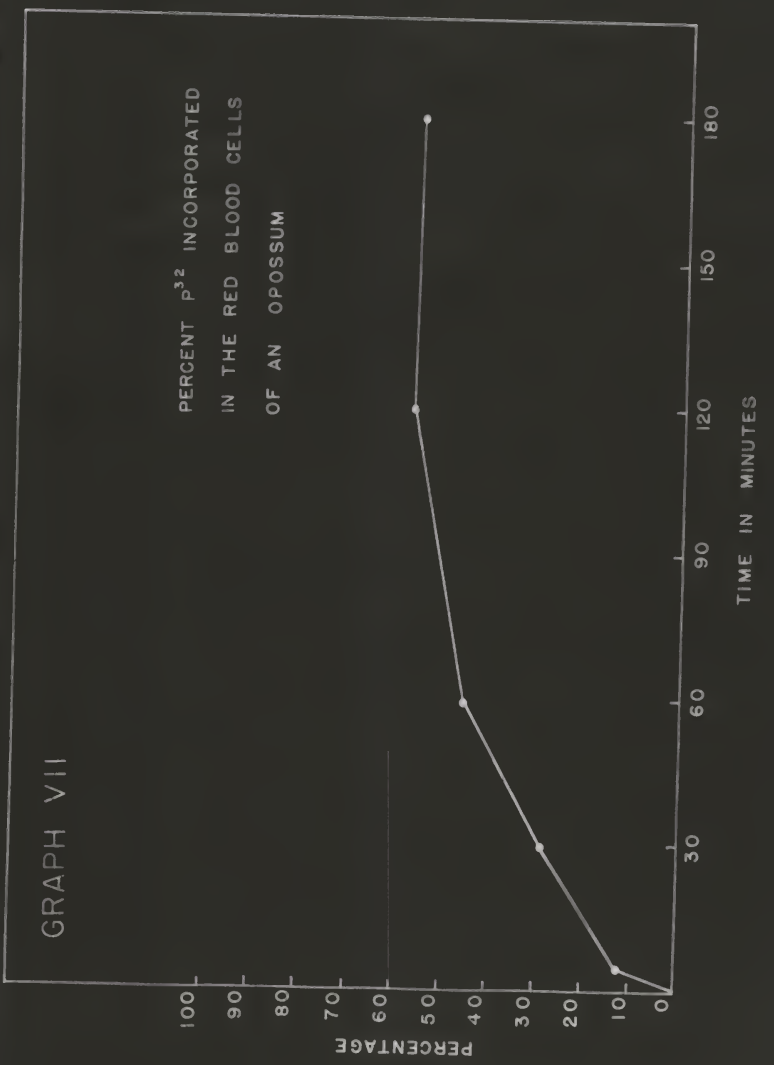


present In the sample at 5 minutes, 28.6 per cent at 30 minutes, 45.3 per cent labelled at 1 hour, 56.4 per cent laberled at 2 hours, and 55.6 per cent labelled at 3 hours.

Other Data In Regard to the Opossum

One opossum which had a red blood call count of 2,420,000 per ome, and $6.3 \mathrm{gm}$. of hemoglobin per $100 \mathrm{co}$. of blood was evidently abnormal for which reason it was not included in Table III. The animal wes a feraile weighing $2345 \mathrm{gm}$. and died within a week after capture.

Other data which may have an important bearing on the results reported here in regard to opossuns studied are given in Table IV. 
TABLES IIT

Oposeun, Didelphis virglniana pigra

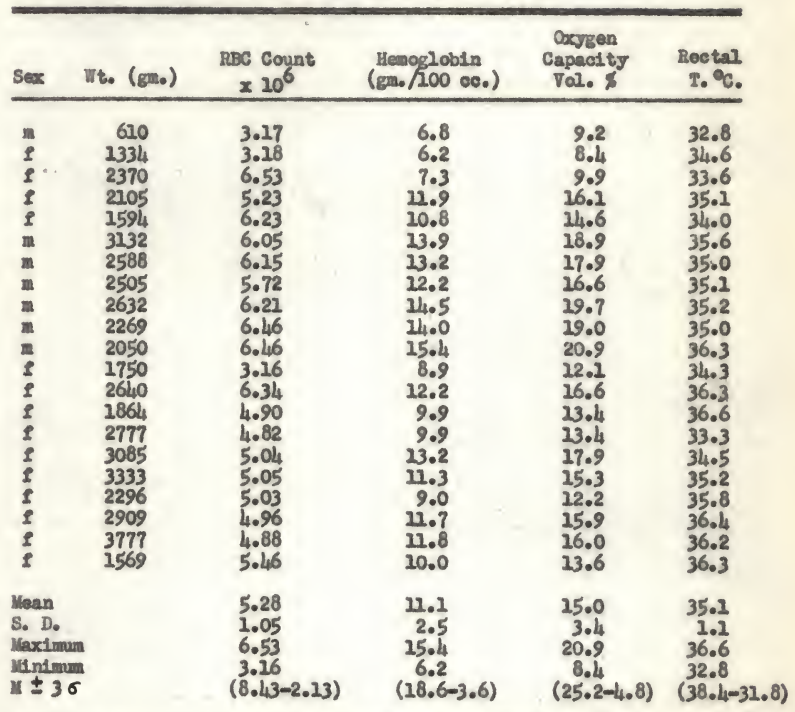

Scott (1938) reports for D. VIrginiana

Maan values for $8 \quad 5.12$

Mean values for 23

24.9

Mean valuos for 16

34.6 


\section{BLOOD VOLUIE DEPERINATIONS IN OTHER ANIMLS}

In addition to the oposeums, the blood volume of one raccoon, one dog, 8 rabb1ts, and 10 swine was 1 mest1gated, as already ment1oned. Data for blood volume in normal animals are given in Table VI.

\section{Racooon}

A male raceoon (Procyon 1otor elucus) welghing $2796 \mathrm{gm}$. had a red blood call count of 7,770,000 per ame, and $11.6 \mathrm{ge}$. of hemoglobin per $100 \mathrm{cc}$. of blood. This animal had a rectal temperature of $37.6^{\circ} \mathrm{C}$.

\section{Dog}

The dog, a male, wolghed 19,051 gas. It had a rod blood cell count of 6,270,000 per onm., and $12.3 \mathrm{gme}$ of hemoglobin per 100 ce. of blood. Thls dog aeened to be part bocker and had been nalntained on kennel food (Purina dog chon) for about 2 nonths before he ws used in the experiment. Ho was not fat, but sleek, had a good hair coat with somewhat of a sheen to $1 \mathrm{t}$, and was a very docile aninal.

Rabblto

S1x rabbits used for blood volume determinations had been malntained by Mr. L. R. Arrington on a diet wich contained different levela of nolybdenum. Two aninala ware used as controls. The oxygen oapacity of each animal was deternined by multiplying the henoglobin concentration In grams per $100 \mathrm{ml}$. of bleod by 1.36 (Bernhart and Steggs, 19/43). The data obtained for the rabbits are presented in Table IV. 


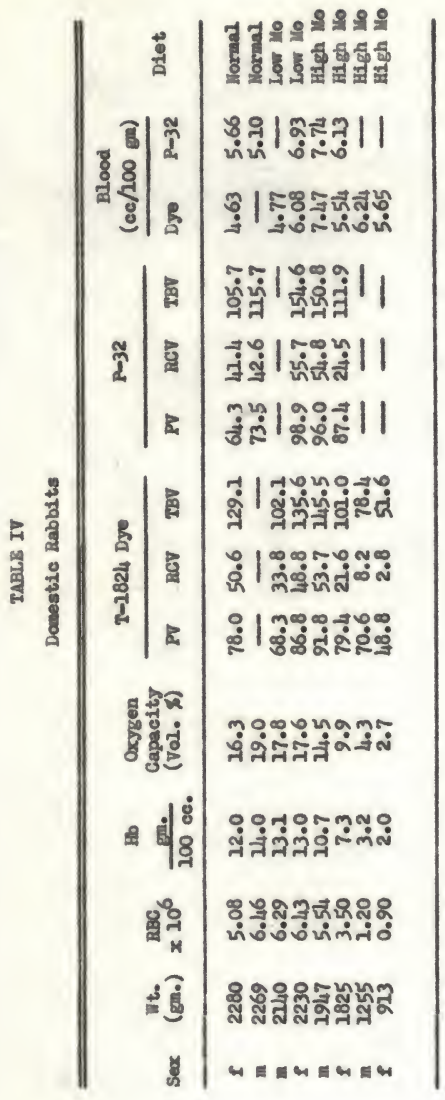




\section{IMVSTIOATIONS OF DUROC-JERSEY SWIME}

The blood volume of 12 pigs was Imvestigated by Heisaler (2886) by bleeding the animal to death and comparing the weight of the collocted blood to the net welght of the animal. The plgs he used wedghed from 31.95 to 228.0 kilograms. He reported a mean blood value of 4.60 per cent of the body weight.

The blood volune of Hampahlre swine using radiosotive phospherus32 was strdied by Hansard 느 으. (2951). There is a mean value of 6.03 ml. of blood per 100 gan. of body weight for 26 swine investigated. The swine ranged in wolight from 3.62 to 167.83 kdlograms.

The reaults of blood valume studies in 10 Duroc-Jersey swine were reperted by Burke, Shirley, and Davis (1951). The pigs they used ranged in weight fron 20.43 to 96.61 kdlograms. The blood valume in 9 of these 10 swine was also imvestigated by the $5-1824$ dye wethod, which has not been previlously reported.

\section{Blood Volume Determinations with T-1824 Dye and P-32}

The T-1824 dye and P-32 methods were coneurrently employed to deternine blood volume in these aninals. About $10 \mathrm{ml}$. of blood were renoved direetly from the heart whth a heparinised 4 inch, 22 gauge needle and ayringe. Sone of the blood was used for a red blood cell count and henoglobin measurement; the rest of the blood was used as Ilsted in the procedure for the T-1824 dye and P-32 methods. The plg welghing 69,400 gm, was treated the same as the others except that the blood renoval and Imjections 
were made through the right and left ear veins, respectively. The T-1824 dye solution was prepared so that it contained either 2 or 4 mgne per ml. Approximately $10 \mathrm{ml}$. (the exsot amount was recorded) or dye solution was Injected direotly into the ventricle of the heart and immediately afterwards the P-32 solution was injected. In Table $\mathrm{V}$ the data are presented that wore obtained for the 10 plgs.

\section{Other Data in Regard to Swine}

The acygen capacity was deternined by aultiplying the hemoglobin In gal. per $100 \mathrm{ml}$. of blood by the factor 1.36 mentioned previously. The mean values for total plasma volume, total red cell volume, and total blood valume as determined with the 5-182/4 dye method were 65 ml. higher, $3 \mathrm{ml}$. lower, and $7 \mathrm{ml}$. higher, respectively, than with the P-32 method.

By using the expression mean plus or minus three times the standard devlation, the red blood cell count has values of 9.59 to $5.55 \times 10^{6}$, for hemoglob1n the values are 13.8 to $8.12 \mathrm{gm}$. per $100 \mathrm{ml}$. of bloods the values for exygen eapacity are 20.3 to 9.5 volumes per cent; the values for total blood valume range rom 15.1 to 2.5 and 14.1 to $3.9 \mathrm{ml}$. of blood per 100 gm. of body welght for the $\mathrm{I}-1824$ dye and $\mathrm{P}-32$ methods, respectively. The data showling the relation of allliliters of blood per kllogran of body weight to weight of the swine obtained by the dye and P-32 methods calculated from samples taken 10 mimites after the injection of the dye and labelled cell solutions are presented in Oraph VIII. These values indicate that there is a dearease in blood volume per idlogram of 


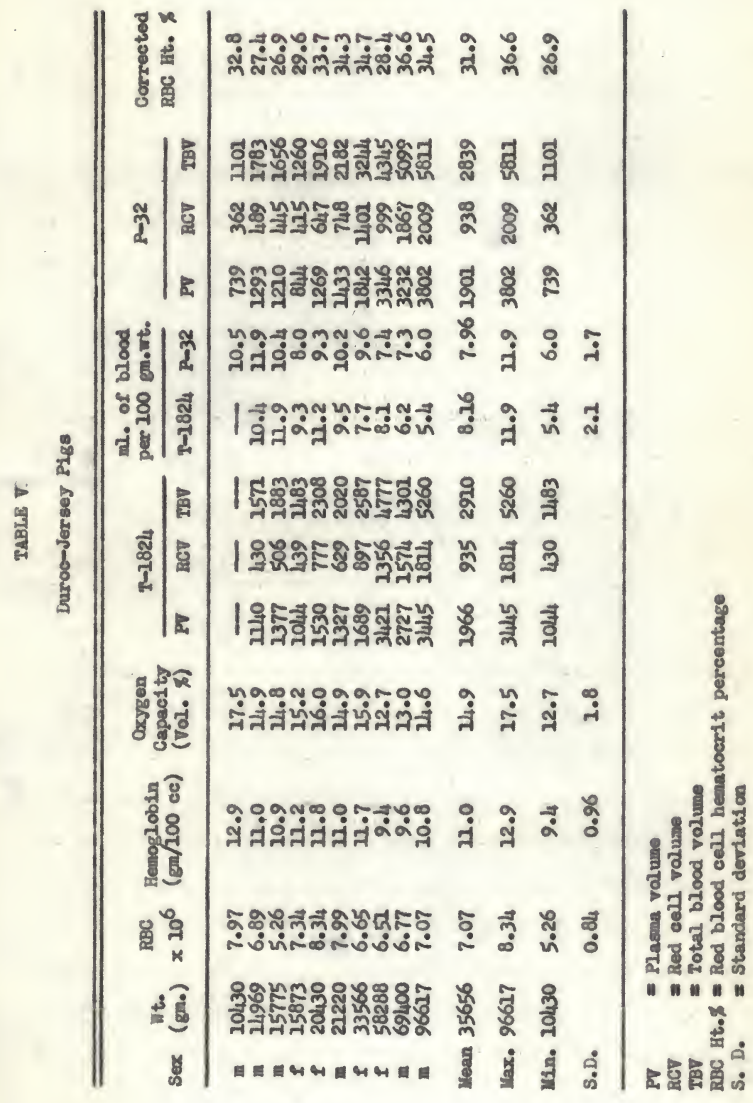




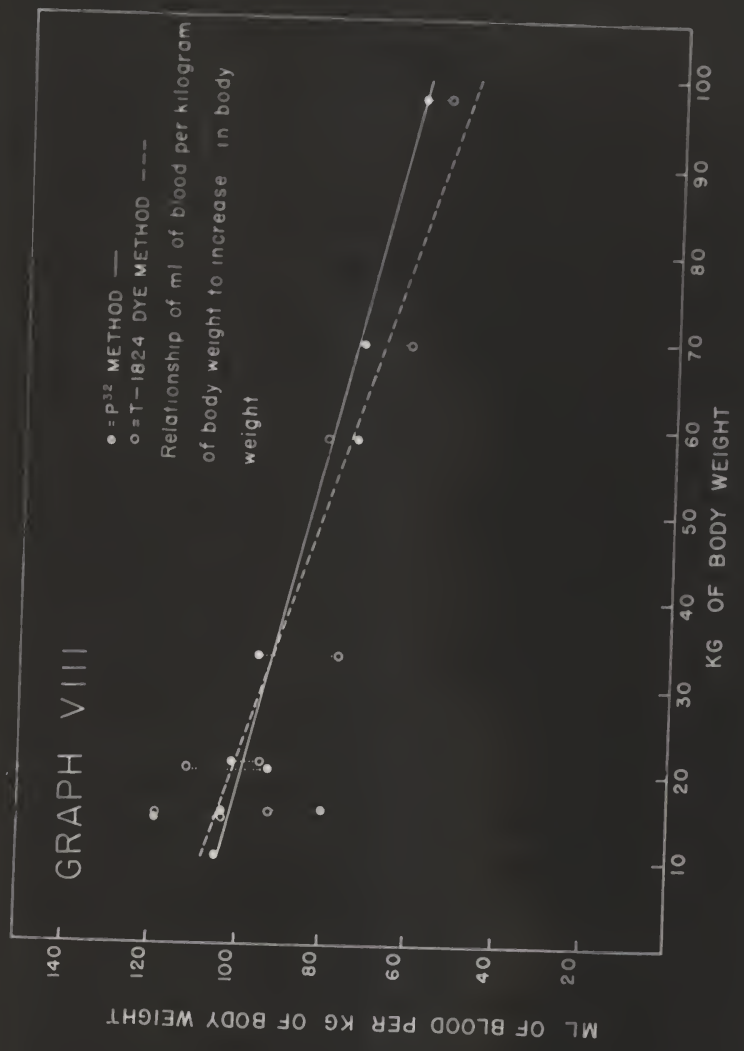


body weight with an inerease in weight of the swine. Th1s relationship shows a good eorrelation for each method when viewod s tatistically. The coefficient of correlation for the $\mathrm{T}-2824$ dye 1 s 87.20 per cent and for the P-32 method is 86.46 per cent. The two best IIt I1nes were detarmined by the previoualy mentioned method of least squares.

In Iine with the findings of Mitchell and Hamilton (1929) and Bull and Carroll (1937) the decrease in blood volume per unit of body weight, which is correlated with an Inerease in body wolght, may be caused by a dearease in water concentration and an increses in fat.

\section{Mlixing Time and Rate of Disappearance of Dye and $\mathrm{P}-32$}

The rate of disappearance of the P-32 and the I-1824 dye from the blood of a pig was measured. The pig weighing 21,220 grans wes used In this experiment. At 30,45 , and 60 mimutes the P-32 concentration was essentially the same as at 10 minutes indicating that the blood was thoroughly mixed within 10 minutes and that few of the labelled cells had lost their activity. Values obtained at $2,3,5,18,24$, and 48 hours after injection shownd a decrease with time as shown on Graph IX. At 1 hour there was 96.0 per cent of the P-32 remaining in the blood, at 3 hours there was 85.5 per eent, 80.6 per cent at 5 hours, 46.5 per cent at 18 hours, 29.0 per cent at 24 hours, and 13.0 per cent at 48 hours remaining. On Craph IX are also plotted the data in relation to the disappearance of the dye from the blood. At 30 , and 45 minutes there was. 91.5 and 85.5 per cent I-1824 dye remeining. At 2 hour 80.7 per cent remained, 


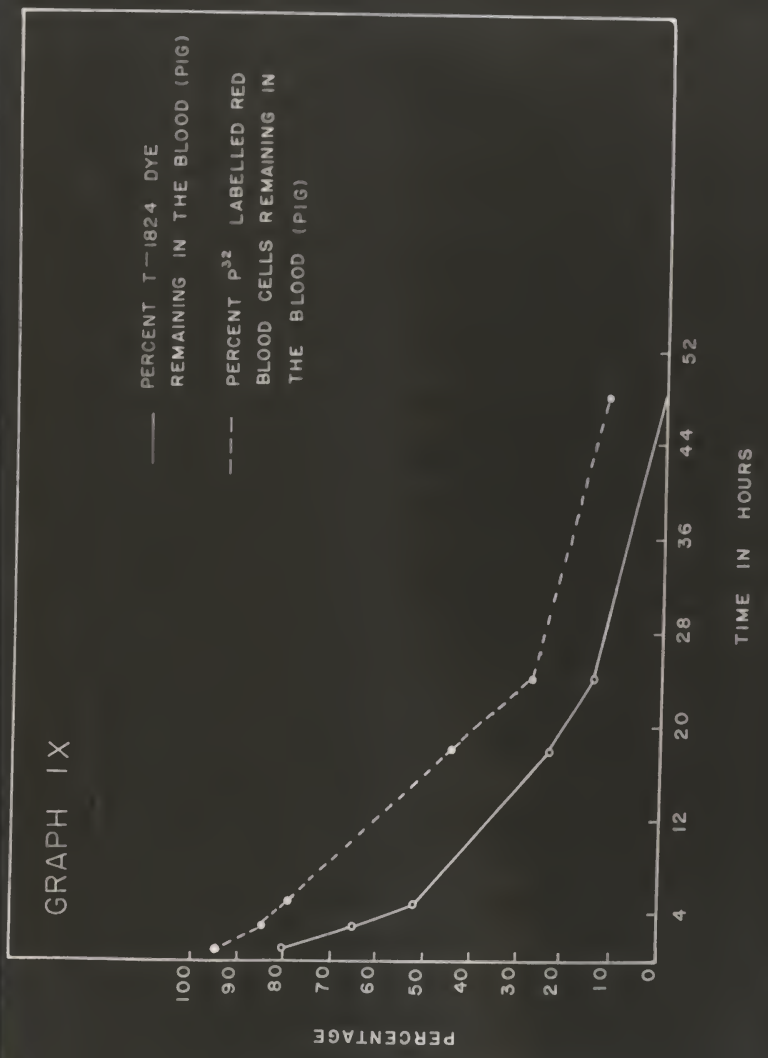


66.2 per cent at 3 hours, 53.0 per cent at 5 hours, 20.4 per cent at 18 hours, 15.6 per cent at 24 hours, and at the end of 48 hours, no moasurable anount of dye remained in the blood.

The disappearance rate of P-32 over a period of 5 days was evaluated in a pig weighing 14,969 grans. There was a larger doge of P-32 given to this pig than to the one weighing 21,220 grans sine the ectivIty of the radiophosphorus was to be evaluated over a longer period. For the p1g welghing 21,220 grams, there was a concentration of P-32 present at 10 minutes of 382 counts per minute per milliliter of blood. For the pig weighing 14,969 grams, the concentration of P-32 at 10 minutes was 961 counts per minute per ailliliter of blood. It was found that in the pig we1ghing $\mathbb{I}_{4}, 969$ grans there was 48.5 per cent of P-32 remalning In the blood at the end of 24 hours, 20.9 per cent at the end of 48 hours, 16.3 per cent at 72 hours, 8.7 per cent at the and of 4 days, and 4.0 per cent remained at the end of 5 days. These values are shown on Graph $x$. 


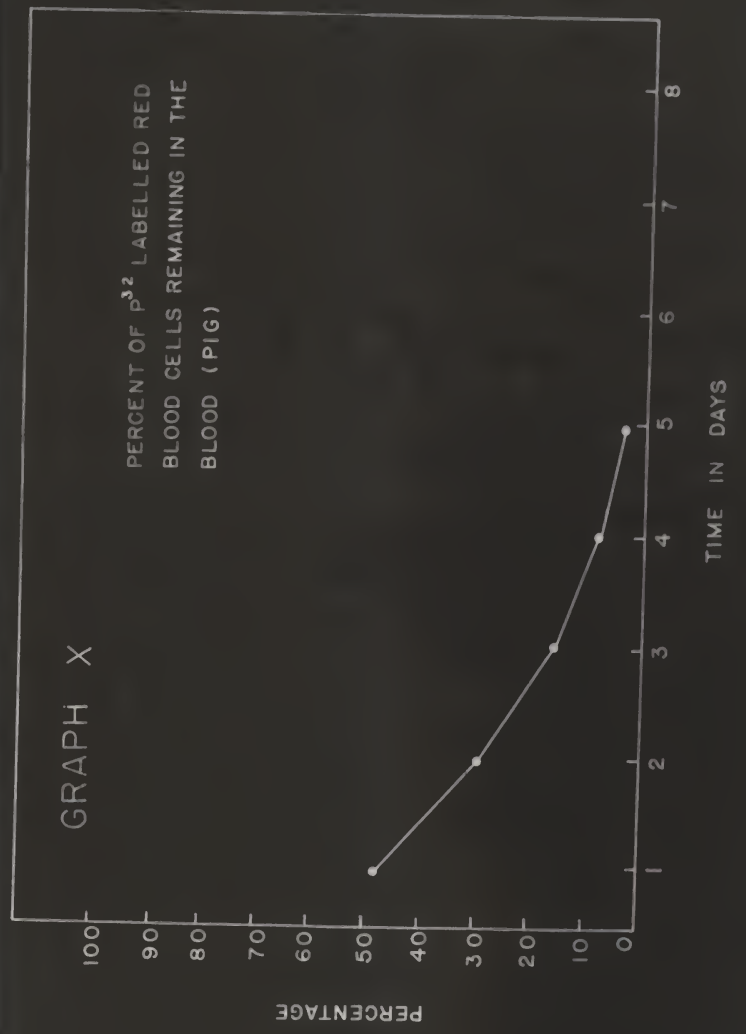




\section{BLOOD VOLUE VALUES FROM AVATUABLE SOURCES}

Blood rolune values are presented in Table VI as the milliliters of blood per 100 grams of body weight. The data appearing in parentheses are those reported by investLgators as the anount of blood present in per cent of body weight of the animal. In arder to aake the two values comparable, the author has converted per cent body welght readings to milliliters of blood per 100 gxams of body weight. This was done by dividing per cent body welght values by the apectfle gravity of blood of different animals as reported by Dukes (1937).

Fron a consideration of the different saterials and mothod anployed in the determination of blood volume in an animal, certain methods have becone obsolete as already explatned. For this reason an asterlak is placed beslde the values in Table VI which sees valid. \& "q" indicates that not enough information is available to we concerming wethods used to evaluate them positively. 
TABLE VI

Blood Volume in ml. per $100 \mathrm{gm}$. of Body Weight

\begin{tabular}{lll}
\hline ORDER \\
Fanily & No. $\begin{array}{l}\text { Blood } \\
\text { Volune Nethod Authority }\end{array}$ \\
\hline
\end{tabular}

MARSUPALIA

Didelphidae

\begin{tabular}{|c|c|c|c|c|}
\hline 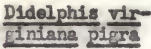 & 10 & -5.83 & Evans blue & Burke \\
\hline$\frac{\text { Didelphis }}{\text { Inians pir }}$ & 10 & *5.49 & $R-32$ & Burke \\
\hline
\end{tabular}

CHIROPTERA

Vespertilionidee

Vespert111s

noctura

2 (8.3) Bleeding

Wel cker-1858

PRIuATES

Hounintase

\begin{tabular}{|c|c|c|c|c|}
\hline Lan & 2 & $7.2(7.7)$ & Bleeding & Bischoff-1856 \\
\hline $\operatorname{Man}$ & 44 & $4.5(4.78)$ & co & Haldane-1899-1900 \\
\hline $\operatorname{Ian}(\mathrm{male})$ & 9 & 5.5 & co & Oerrume-1908 \\
\hline Man (female) & 3 & 4.9 & co & Derum-2908 \\
\hline $\operatorname{Man}$ & 4 & $5.2(5.58)$ & CO & P1esh-1909 \\
\hline $\operatorname{Man}$ & 2 & $7.2(7.5)$ & co & Douglas-1910 \\
\hline Man & 6 & 5.95 & co & Salvesen-1919 \\
\hline $\operatorname{Man}$ & 6 & 6.8 & co & Smith $-1924-25$ \\
\hline $\operatorname{Man}$ & 16 & 6.42 & co & Chang-1928 \\
\hline $\operatorname{Man}$ (Infants) & 10 & 7.1 & co & MeIntosh-1929 \\
\hline Man (hor Isontal) & 8 & 7.14 & co & Waterfleld-1931 \\
\hline Man (vertical) & 8 & 6.45 & co & Waterf1eld-1931 \\
\hline Man & 12 & 6.07 & co & Brednow-1931 \\
\hline $\operatorname{Man}$ & & 9.62 & Co & Basett -1940 \\
\hline Man & 10 & 9.7 & co & Asmussen-1942 \\
\hline Man & 9 & 10.13 & Co & Hevesy-1943-444 \\
\hline $\operatorname{Man}$ & 9 & 8.02 & co & Hopper-1944 \\
\hline
\end{tabular}


TABLE VI (Contimued)

Blood Volume in in. per 100 gm. of Body Weight

\begin{tabular}{|c|c|c|c|c|}
\hline $\begin{array}{l}\text { ORDER } \\
\text { Tamily }\end{array}$ & No. & $\begin{array}{l}\text { Blood } \\
\text { Volume }\end{array}$ & Mothod & Authority \\
\hline Man & 12 & $7 \cdot 44$ & co & Courtice-1949a \\
\hline $\operatorname{Man}$ & 4 & $7.8(8.3)$ & $\mathrm{NaCl}$ & Kottaann-1906 \\
\hline Man & 10 & $7.4(7.9)$ & $\begin{array}{l}\text { Tetamus ant1- } \\
\text { tocin }\end{array}$ & Fries-19u \\
\hline Ian & 18 & 8.90 & V1tal red & Ke1th-1915 \\
\hline Man & 5 & 8.7 & Vital red & Bock-1921 \\
\hline Man (Infants) & 30 & $u_{60} ?$ & Vital red & Inces-1921 \\
\hline Jan & 11 & $4.6(4.9)$ & Vital red & Lindhard-1926a \\
\hline Nan (infants) & 35 & 7.6 & Vital red & Darrow-1928 \\
\hline Man & 11 & 8.90 & Vital red & Brednom-1932 \\
\hline $\operatorname{Man}$ & 2 & 7.12 & Vital red & D1ecknam-1934. \\
\hline $\operatorname{Man}$ & 2 & 7.4 & V1tal red & Fxiedlander -2936 \\
\hline Itan (infants) & 36 & 10.1 & Br. vital red & Bakmin-1924 \\
\hline Ian & 6 & 9.6 & Br. vital red & Satth-1924-25 \\
\hline Man & 10 & 9.3 & Br. vital red & MoIntosh-1929 \\
\hline Kan & 20 & 8.7 & Br. vital red & Robinow-1940 \\
\hline Man & & 10.32 & Congo red & Basett-19/40 \\
\hline Man (male) & 49 & 8.86 & Congorvital red. & Rountree-2929 \\
\hline Man (remaile) & 25 & 8.57 & Congomital red & Rowntree-1929 \\
\hline Man & 16 & $* 7.26$ & Evans blue & Cibson-19378 \\
\hline Man (male) & 49 & $* 7.72$ & Bvans blue & Gibson-1937b \\
\hline $\operatorname{Man}$ ( Iemale) & 41 & $\% 6.61$ & Evans blue & Gibson-1937b \\
\hline Ian & 15 & $* 7.99$ & Dvans blus & Harrington-1940 \\
\hline Ian (children) & 16 & 48.20 & Bvans blue & Schluts -1940 \\
\hline Man & 10 & $* 9.2$ & Evans blue & Asmussen-2942 \\
\hline Man (Infants) & 9 & $* 6.99$ & Evans blue & Brines-1941 \\
\hline Man (ch1Idren) & 41 & $* 6.99$ & Dvans blue & Br1nes-1941 \\
\hline Man & 11 & $* 7.67$ & Evans blue & Dav1s-1942 \\
\hline Man & 9 & *8.83 & Evans blue & Hevesy-19/43-44 \\
\hline Man & 9 & $* 8.05$ & Evans blue & Hopper-1944 \\
\hline Man & 40 & 9.3 & Bvans blue & 01bson-1946 \\
\hline Han (plasma) & 25 & $* 8.07$ & Evans blue & Mtsche-1947 \\
\hline $\operatorname{Man}$ (serrun) & 25 & 7.66 & Evans blue & M tsche-1947 \\
\hline Man & 6 & -7.8 & Bvans blue & Mayerson-1948 \\
\hline
\end{tabular}


TABLE VI (Contimued)

Blood Voluae in mi. per $100 \mathrm{gm}$. of Body Weight

\begin{tabular}{|c|c|c|c|c|}
\hline $\begin{array}{l}\text { ORDER } \\
\text { Fandly }\end{array}$ & No. & $\begin{array}{l}\text { Blood } \\
\text { Volune }\end{array}$ & Mothod & Authority \\
\hline $\begin{array}{l}\text { Man } \\
\text { Man (male) } \\
\text { Man (fenale) }\end{array}$ & $\begin{array}{l}12 \\
25 \\
24\end{array}$ & $\begin{array}{l}* 7.25 \\
* 8.26 \\
* 7.78\end{array}$ & $\begin{array}{l}\text { Bvans blue } \\
\text { Bvans blue } \\
\text { Evans blue }\end{array}$ & $\begin{array}{l}\text { Courtice-1949a } \\
\text { Gregersen-19499 } \\
\text { Cregersen-19/49 }\end{array}$ \\
\hline Man & 33 & 88.13 & $\begin{array}{l}\text { Sodive thio- } \\
\text { eyanato }\end{array}$ & Stewart-1940 \\
\hline $\begin{array}{l}\operatorname{Man} \\
\operatorname{Man} \\
\operatorname{Man} \\
\operatorname{Man} \\
\operatorname{Man} \\
\operatorname{Man}\end{array}$ & $\begin{array}{l}2 \\
9 \\
6 \\
9 \\
6 \\
5\end{array}$ & $\begin{array}{l}7.4 \\
* 7.83 \\
* 7.35 \\
* 6.98 \\
* 7.6 \\
* 6.73\end{array}$ & $\begin{array}{l}P-32 \\
P-32 \\
P-32 \\
P-32 \\
P-32 \\
P=32\end{array}$ & $\begin{array}{l}\text { Govaerts }-2942 \\
\text { Hevesg-1943-444 } \\
\text { Nylin-1945 } \\
\text { Kally-1948 } \\
\text { Naverson-1948 } \\
\text { Scott-1951 }\end{array}$ \\
\hline Wonkey & 2 & $(8.25)$ & $\begin{array}{l}\text { Sodium chloride } \\
\text { gpecifie } \\
\text { gravity }\end{array}$ & Sherrington-1893 \\
\hline
\end{tabular}

\section{LACOMORPHA}

Leporidae

\begin{tabular}{|c|c|c|c|c|}
\hline $\begin{array}{l}\text { Rabbit } \\
\text { Rabb1t } \\
\text { Rabb1t } \\
\text { Rabbit } \\
\text { Rabb1t } \\
\text { Rabbit (nale) }\end{array}$ & $\begin{array}{r}5 \\
15 \\
9 \\
22 \\
52 \\
6\end{array}$ & $\begin{array}{l}5.2(5.55) \\
3.9(4.13) \\
7.4(7.8) \\
4.6(4.92) \\
4.77 \\
6.6(7.0)\end{array}$ & $\begin{array}{l}\text { Bleeding } \\
\text { Bleeding } \\
\text { Bleeding } \\
\text { Bleeding } \\
\text { Bleeding } \\
\text { Bleeding }\end{array}$ & $\begin{array}{l}\text { Wel eker-1858 } \\
\text { Ranke-187 } \\
\text { Steinberg-1873 } \\
\text { Drejer-1910-21 } \\
\text { Boyeott-1912-22 } \\
\text { Levino-1943 }\end{array}$ \\
\hline Rabbit & 8 & $8.0(8.4)$ & $\begin{array}{l}\text { Sodivm-ohlaride } \\
\text { specific } \\
\text { gravity }\end{array}$ & Sherrington-189 \\
\hline Rabb1t & 1 & $7.8(8.21)$ & Hemoglob1n & Barratt-1909 \\
\hline Rabbit & 24 & $5.3(5.66)$ & Servan ppt. & Schuree-1912 \\
\hline Rabbit & 2 & $6.0(6.3)$ & Antitorin & Von Bering-2911 \\
\hline Rabb1t & 52 & 4.9 & Ringer's & Boycott-1914 \\
\hline
\end{tabular}


TABLE VI (Continued)

Blood Volume in ml. per $100 \mathrm{gm}$. of Body Weight

\begin{tabular}{|c|c|c|c|c|}
\hline $\begin{array}{l}\text { ORDER } \\
\text { Fanily }\end{array}$ & No. & $\begin{array}{l}\text { Blood } \\
\text { Volven }\end{array}$ & Method & Authority \\
\hline $\begin{array}{l}\text { Rabb1t (male) } \\
\text { Rabb1t (famale) } \\
\text { Rabbit } \\
\text { Rabb1t } \\
\text { Rabbit } \\
\text { Rabbit } \\
\text { Rabb1t } \\
\text { Rabb1t (male) } \\
\text { Rabb1t (female) } \\
\text { Rabb1t }\end{array}$ & $\begin{array}{r}7 \\
4 \\
3 \\
22 \\
11 \\
36 \\
126 \\
7 \\
7 \\
15\end{array}$ & $\begin{array}{l}4.6(4.85) \\
5.0(5.32) \\
6.3(6.7) \\
5.37 \\
5.3(5.6) \\
5.36 \\
5.1(5.45) \\
4.95 \\
5.0 \\
5.77\end{array}$ & $\begin{array}{l}c 0 \\
\mathrm{CO} \\
\mathrm{CO} \\
\mathrm{CO} \\
\mathrm{CO} \\
\mathrm{CO} \\
\mathrm{CO} \\
\mathrm{CO} \\
\mathrm{CO} \\
\mathrm{CO}\end{array}$ & $\begin{array}{l}\text { Douglas-1906 } \\
\text { Douglas-1906 } \\
\text { Oerue-1908 } \\
\text { Boycott-1909 } \\
\text { Nelson-1909 } \\
\text { Boyoott-1911-12 } \\
\text { Dreyer-1913 } \\
\text { Salvesen-1919 } \\
\text { Salvesen-1919 } \\
\text { Courtice-19496 }\end{array}$ \\
\hline $\begin{array}{l}\text { Rabbit } \\
\text { Rabbit }\end{array}$ & $\begin{array}{l}7 \\
4\end{array}$ & $\frac{5.44}{6.49}$ & $\begin{array}{l}\text { Acacia } \\
\text { Acacia }\end{array}$ & $\begin{array}{l}\text { Meels-1918-19 } \\
\text { MeQuarr1e-1920 }\end{array}$ \\
\hline $\begin{array}{l}\text { Rabb1t } \\
\text { Rabb1t }\end{array}$ & $\begin{array}{l}13 \\
11\end{array}$ & $\begin{array}{l}8.2(8.7) \\
9.1(9.6)\end{array}$ & $\begin{array}{l}\text { Vital red } \\
\text { Vital red }\end{array}$ & $\begin{array}{l}\text { Went-1929 } \\
\text { Nice-1934 }\end{array}$ \\
\hline Rabb1t & 24 & $75.5(5.82)$ & Precipltin & Culbertson-2934 \\
\hline $\begin{array}{l}\text { Rabbit } \\
\text { Rabbit } \\
\text { Rabbit } \\
\text { Rabbit }\end{array}$ & $\begin{array}{l}60 \\
15 \\
39 \\
1\end{array}$ & $\begin{array}{l}* 7.0 \\
* 5.75 \\
* 6.98 \\
* 4.63\end{array}$ & $\begin{array}{l}\text { Evans blue } \\
\text { Evans blue } \\
\text { Evans blue } \\
\text { Bvans blue }\end{array}$ & $\begin{array}{l}\text { Court1ce-19/3 } \\
\text { Court1ce-1949b } \\
\text { Alkawa-1950 } \\
\text { Burke }\end{array}$ \\
\hline $\begin{array}{l}\text { Rabb1t } \\
\text { Rabb1t } \\
\text { Rabb1t }\end{array}$ & $\begin{array}{l}2 \\
9 \\
2\end{array}$ & $\begin{array}{l}* 4.7 . \\
\$ 5.3 \\
* 5.38 .\end{array}$ & $\begin{array}{l}p=32 \\
P-32 \\
P=32\end{array}$ & $\begin{array}{l}\text { Hahn-1940 } \\
\text { Anderson-1942 } \\
\text { Burke }\end{array}$ \\
\hline
\end{tabular}

\section{RODEMTIA}

Muridae

\begin{tabular}{|c|c|c|c|c|}
\hline Mice & 5 & $7.3(7.7)$ & Bleeding & Welckex-1858 \\
\hline 1100 & 19 & $5.4(5.77)$ & Bleeding & Dreyer-1910-21 \\
\hline Mice & 12 & $4.9(5.2)$ & Bleeding & Furth-1946 \\
\hline Rat (albino) & 15 & 4.5 & Bleeding & Ja11y-1905 \\
\hline Rat & 25 & 5.8 & Bleoding & Ch1solm-1911 \\
\hline Rat & 87 & 6.28 & Bleoding & Boyeott-1911-12 \\
\hline Rat (male) & 46 & 6.35 & Bleeding & Dakezey-1940 \\
\hline Rat (female) & 54 & 6.29 & Bleeding & Dakczey-2940 \\
\hline Rat & 4 & 5.59 & Bleeding & aruneberg-1942 \\
\hline Rat (albino) & 10 & 5.25 & Bleeding & Barlow-1929 \\
\hline
\end{tabular}


TABLE VI (Continued)

\begin{tabular}{|c|c|c|c|c|}
\hline $\begin{array}{l}\text { ORDER } \\
\text { Fantily }\end{array}$ & Ho. & $\begin{array}{l}\text { Blood } \\
\text { Volume }\end{array}$ & Method & Authority \\
\hline $\begin{array}{l}\text { Rat } \\
\text { Rat } \\
\text { Rat (aingle) } \\
\text { Rat (parabotic) } \\
\text { Rat (albino) } \\
\text { Rat (at } \\
\text { Rat } \\
\text { Rat }\end{array}$ & $\begin{array}{r}8 \\
9 \\
4 \\
7 \\
8 \\
20 \\
16 \\
6\end{array}$ & $\begin{array}{l}6.4(6.8) \\
7.0(7.4) \\
9.72 \\
20.21 \\
6.38 \\
4.3 \\
4.5 \\
6.6(7.02)\end{array}$ & $\begin{array}{l}\text { Vital red } \\
\text { Vital red } \\
\text { Vital red } \\
\text { Vital red } \\
\text { Vital red } \\
\text { Vital red } \\
\text { Vital red } \\
\text { Vital red }\end{array}$ & $\begin{array}{l}\text { Cartland-1928 } \\
\text { Went-1929 } \\
\text { H1II-1933 } \\
\text { H111-1933 } \\
\text { Orten-1933 } \\
\text { Griffth-1937 } \\
\text { Criffith-1940 } \\
\text { Evans-1941 }\end{array}$ \\
\hline 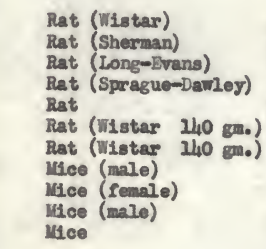 & $\begin{array}{r}53 \\
34 \\
18 \\
9 \\
23 \\
20 \\
49 \\
3 \\
2 \\
6 \\
9\end{array}$ & $\begin{array}{l}* 7.98 \\
* 8.9 \\
* 8.9 \\
* 8.28 \\
16.17 \\
* 9.0 \\
* 7.0 \\
311.27 \\
811.64 \\
89.36 \\
310.3 .(10.9)\end{array}$ & $\begin{array}{l}\text { Evans blue } \\
\text { Evans blue } \\
\text { Evans blue } \\
\text { Evans blue } \\
\text { Evans blue } \\
\text { Evans blue } \\
\text { Evans blue } \\
\text { Evans blue } \\
\text { Evans blue } \\
\text { Evans blue } \\
\text { Evans blue }\end{array}$ & $\begin{array}{l}\text { Beciswith-1941] } \\
\text { Metcorf-1944 } \\
\text { lioehtner-1945 } \\
\text { Stanley-1946 } \\
\text { Benditt-1946 } \\
\text { Wang-1949 } \\
\text { Wang-1949 } \\
\text { Wish-1950 } \\
\text { Wiah-1950 } \\
\text { Wish-1950 } \\
\text { Furth-1946 }\end{array}$ \\
\hline Rat & 10 & 6.13 & $\infty$ & Scott-1924 \\
\hline Rat & 125 & 6.9 & Henoglobin & ILippnan-1947 \\
\hline $\begin{array}{l}\text { Rat (Slonaker) } \\
\text { Rat (Slonsaker } x\end{array}$ & 12 & $* 4.87$ & $P \sim 32$ & Berlin-19/49 \\
\hline $\begin{array}{l}\text { Gurtis-Duning) } \\
\text { Mice (male) } \\
\text { Hice (female) } \\
\text { Hice (male) }\end{array}$ & $\begin{array}{r}30 \\
3 \\
2 \\
6\end{array}$ & $\begin{array}{l}4.52 \\
77.52 \\
37.18 \\
36.39\end{array}$ & $\begin{array}{l}P-32 \\
P=32 \\
P=32 \\
P=32\end{array}$ & $\begin{array}{l}\text { Ber2in-1949 } \\
\text { Wish-1950 } \\
\text { Wish }-2950 \\
\text { Wish }-1950\end{array}$ \\
\hline $\begin{array}{l}\text { Rat (Slonaker) } \\
\text { Rat (Sprague-Davley) }\end{array}$ & $\begin{array}{l}12 \\
12\end{array}$ & $\begin{array}{l}* 4.75 \\
* 4.87\end{array}$ & $\begin{array}{l}\text { Fe-59 } \\
\text { Fe-59 }\end{array}$ & $\begin{array}{l}\text { Berlin-1949 } \\
\text { Sharpe-1950 }\end{array}$ \\
\hline Rat (Sprague-Dawley) & 4 & .5 .26 & Fe-55 & Sharpe-1950 \\
\hline Rat (Sprague-Dawley) & 6 & . जै4.9 & $\begin{array}{l}\text { Fe-55 } \\
\text { Hernoglobin }\end{array}$ & Sharpe-1950 \\
\hline
\end{tabular}


TABLE VI (Continued)

\begin{tabular}{|c|c|c|c|c|}
\hline $\begin{array}{l}\text { ORDER } \\
\text { ranily }\end{array}$ & No. & $\begin{array}{l}\text { Blood } \\
\text { Voluse }\end{array}$ & Nothod & Authority \\
\hline Giridae & & & & \\
\hline Myocus g11s & 3 & $5.5(5.8)$ & Bleeding & Welckex-1858 \\
\hline Cavlidae & & & & 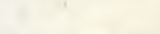 \\
\hline Cuinea p1g & 6 & $(7.8)$ & Bleeding & Stelnberg-1873 \\
\hline Cuines pig & 9 & $(4.20)$ & Bleeding & Ireyer-1910-11 \\
\hline Cuinea p1g & 18 & $(6.4)$ & Vital red & Went-1929 \\
\hline
\end{tabular}

CARNIVORA

Ganidae

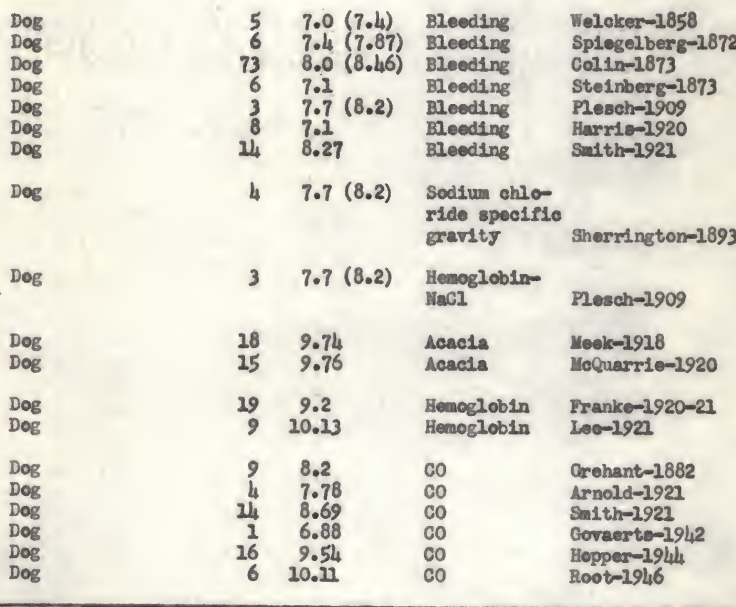


TABLS VI (Continued)

Blood Volume in mi. per $100 \mathrm{gm}$. of Body weight

\begin{tabular}{|c|c|c|c|c|}
\hline $\begin{array}{l}\text { ORDER } \\
\text { Fanily }\end{array}$ & Ho. & $\begin{array}{l}\text { Blood } \\
\text { Volume }\end{array}$ & Method & Anthorlty \\
\hline $\begin{array}{l}\text { Dog } \\
\text { Dog } \\
\text { Dog (male) } \\
\text { Dog (fomale) } \\
\text { Dog }\end{array}$ & $\begin{array}{r}4 \\
22 \\
16 \\
16 \\
106\end{array}$ & $\begin{array}{l}8.4(8.9) \\
10.13 \\
7.30 \\
7.06 \\
10.3\end{array}$ & $\begin{array}{l}\text { V1tal red } \\
\text { Vital red } \\
\text { Vital red } \\
\text { Vital red } \\
\text { Vital red }\end{array}$ & $\begin{array}{l}\text { Harr } 18-1920 \\
\text { Hooper-1920 } \\
\text { Le1chsenring }-1932 \\
\text { Leichsenring }-1932 \\
\text { Crus-1945 }\end{array}$ \\
\hline $\begin{array}{l}\text { Dog } \\
\text { Dog } \\
\text { Dog } \\
\text { Dog }\end{array}$ & $\begin{array}{r}3 \\
3 \\
10\end{array}$ & $\begin{array}{l}12.0 \\
20.39 \\
8.5-9.0 \\
8.22\end{array}$ & $\begin{array}{l}\text { Br.vital red } \\
\text { Br.vital red } \\
\text { Br.vital red } \\
\text { Br.vital red }\end{array}$ & $\begin{array}{l}\text { Sulth-1920 } \\
\text { Suith-1921 } \\
\text { Dav1s-1940 } \\
\text { Hahn-1942 }\end{array}$ \\
\hline $\begin{array}{l}\text { Dog } \\
\text { Dog }\end{array}$ & 25 & $21.07(7.6)$ & $\begin{array}{l}\text { Congo red } \\
\text { Congo red }\end{array}$ & $\begin{array}{l}\text { Harr1-1920 } \\
\text { Powers-1930 }\end{array}$ \\
\hline Dog & 6 & 9.3 & Dyes & Dawson-1920 \\
\hline $\begin{array}{l}\text { Dog } \\
\text { Dog } \\
\text { Dog } \\
\text { Dog } \\
\text { Dog } \\
\text { Dog } \\
\text { Dog } \\
\text { Dog } \\
\text { Dog }\end{array}$ & $\begin{array}{r}50 \\
106 \\
29 \\
16 \\
39 \\
6 \\
6 \\
10 \\
1\end{array}$ & $\begin{array}{c}* .27 \\
* 8.32 \\
* 7.9 \\
* 9.52 \\
* 10.0 \\
* 10.18 \\
* 9.66 \\
* 10.5 \\
* 0.92\end{array}$ & $\begin{array}{l}\text { Evans blue } \\
\text { Dvans blue } \\
\text { Evans blue } \\
\text { Evans blue } \\
\text { Evans blue } \\
\text { Evans blue } \\
\text { Evans blue } \\
\text { Evans blue } \\
\text { Evans blue }\end{array}$ & $\begin{array}{l}\text { Albson-1938 } \\
\text { Bonnycast1e-19/42 } \\
\text { Courtice-1943 } \\
\text { Bopper-1944 } \\
\text { Gibson-1946 } \\
\text { Root-1946 } \\
\text { Bonnyeast1e-1947 } \\
\text { Rrieger-1948 } \\
\text { Burlce }\end{array}$ \\
\hline Dog & 6 & \#.77 & Radiolron & Hahn-1941 \\
\hline Dog & 13 & $* 6.61$ & Fe-59 & Hahn-19/2 \\
\hline $\begin{array}{l}\text { Dog } \\
\text { Dog } \\
\text { Dog }\end{array}$ & $\begin{array}{r}1 \\
10 \\
1\end{array}$ & $\begin{array}{l}16.73 \\
=9.1(9.7) \\
=9.74\end{array}$ & $\begin{array}{l}p-32 \\
p=32 \\
p=32\end{array}$ & $\begin{array}{l}\text { Corraerts-1942 } \\
\text { Krieger-1948 } \\
\text { Burike }\end{array}$ \\
\hline Dog & 10 & $38.9(9.4)$ & $I-231$ & Krieger-1948 \\
\hline
\end{tabular}

Procyonidise

Procyon lotor elucus 1 *8.5 Bvans blue Burike 
TABLE VI (Continued)

Blood Volume in ml. per 100 gm. of Body Weight

\begin{tabular}{|c|c|c|c|c|}
\hline $\begin{array}{l}\text { ORDER } \\
\text { Family }\end{array}$ & Ho. & $\begin{array}{l}\text { Blood } \\
\text { Volune }\end{array}$ & Method & Authority \\
\hline \multicolumn{5}{|l|}{ Felidee } \\
\hline $\begin{array}{l}\text { Cat } \\
\text { Cat } \\
\text { Cat }\end{array}$ & $\begin{array}{l}1 \\
9 \\
2\end{array}$ & $\begin{array}{l}6.1(6.5) \\
7.4(7.8) \\
4.5(4.8)\end{array}$ & $\begin{array}{l}\text { Bleading } \\
\text { Bleeding } \\
\text { Bleeding }\end{array}$ & $\begin{array}{l}\text { Walcker-1858 } \\
\text { Ste1rberg-1873 } \\
\text { Harr1s-1920 }\end{array}$ \\
\hline Cat & 8 & $5.2(5.5)$ & Acacla & Leek-1918 \\
\hline $\begin{array}{l}\text { Cat } \\
\text { Cat } \\
\text { Cat }\end{array}$ & $\begin{array}{l}2 \\
6 \\
4\end{array}$ & $\begin{array}{l}5.9(6.3) \\
5.8(6.2) \\
5.55\end{array}$ & $\begin{array}{l}\text { Vital red } \\
\text { Vital red } \\
\text { V1tal red }\end{array}$ & $\begin{array}{l}\text { Harr18-1920 } \\
\text { Went-1929 } \\
\text { Frledlander-1936 }\end{array}$ \\
\hline Cat & 3 & $5.2(5.5)$ & Congo red & Harrig-1920 \\
\hline
\end{tabular}

\section{PERISSODACTITA}

Equidae

$\begin{array}{lccll}\text { Horse } & 77 & 8.2(8.72) & \text { Bleeding } & \text { Colin-1873 } \\ \text { Horse } & 38 & 9.2(9.75) & \text { Bleeding } & \text { Helssler-1886 } \\ \text { Horse } & 2 & 7.2 & \text { Evans blue } & \text { Court1ee-1943 }\end{array}$

\section{ARTIODACTIAA}

Suidae

$\begin{array}{lclll}\text { P1g } & 12 & 4.3(4.60) & \text { Bleeding } & \text { Heiseler-1886 } \\ \text { P1g (Duroc-Jersey) } & 10 & \# 7.96 & \text { P-32 } & \text { Burke-1951 } \\ \text { P1g (Hampsh1re) } & 16 & * 6.03 & \text { P-32 } & \text { Hansard-1951 } \\ \text { P1g (Duroc-Jersey) } & 9 & * 8.16 & \text { Evans blue } & \text { Burke }\end{array}$

Bovidae

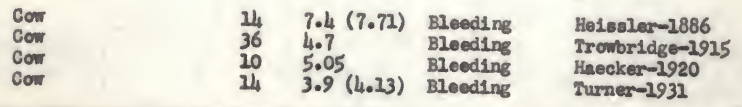


TABLS VI (Contimed)

Blood Volume in ml, per $100 \mathrm{gm}$, of Body Weight

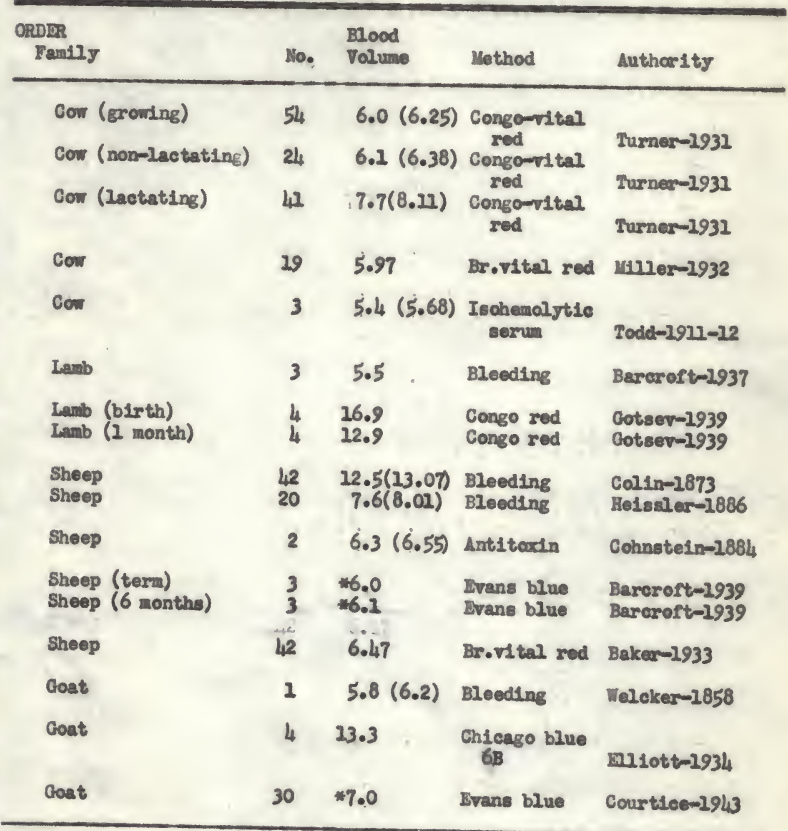




\section{DETERIMATION OF OXYOEN CAPACITY OF THE BLOCD}

ObvLously there is a direot relation between total blood volume and total caggen capacity of the blood. Various attempts to deternine exggen eapacity have been made.

\section{Obsalete Methods}

$\Lambda$ measurement of the arygen capacity of a porpolse and of a dog which weighed 15.5 and $13.8 \mathrm{kd}$ ograns, respectively, was made by Jalyet and Sellier (1896-1897) who used the carbon monocide method of deternining total blood valume described by Grehant and Quinquand. They messured the saturation of the blood with earbon anoxide by letting the antmel breathe a known anount of carbon monoxide and colorimetrically comparing the withdram aample of blood with a standard in which definite anount of blood was saturated with a known amount of carbon monoxide. Irom this percentage of saturation of the blood, the total axygen capacity was determinable, since a molecule of carbon monoxide replaces a malecule of axygen In combination with hemoglobin.

The total blood valune of elther aninal was not reparted, but total bleod valume can be determined if total oxygen capacity is known. Jalyet and Sellier report that the total exygen capacity of the porpolae was 726 cuble centimeters and that the blood had 30.9 cublc centineters of exygen comblned with 100 cublo centimeters of blood. The totel blood volume can be calculated ass. $726 \mathrm{cc} . \times 100 / 30.9 \mathrm{cc} .=2994.2 \mathrm{cc}$. of blood. The erount of blood present per 100 grams of body weight 1 s: 
$2994.2 \mathrm{ce} . / 2,500 \mathrm{gm}, x 100 \mathrm{gm},=29.3 \mathrm{cc} . / 200 \mathrm{gm}$, body weight. These are the only avallable data in regard to the total blood volune of a cetacean. Likemise, the total blood volume of the dog ean be ealculated fram thelr data, since they report that the total exygen capacity of the dog they studied was $550 \mathrm{cc}$. and 1t had an oxygen oapecity of 23.6 volumes per cent. The total blood rolume would bes $550 \mathrm{ce} . \times 100 / 23.6 \mathrm{cc} .=2326.5 \mathrm{cc}$. of blood. The amount of blood present per $100 \mathrm{gm}$, of body welght iss $2326.5 / 13,800 \mathrm{gm}, x 100 \mathrm{gm}$. $=16.8 \mathrm{gme}$ of body we1ght. The total blood valume of the dog determined by this method 1s noticeably higher than the findings of other Investigators as reported in rable vI. The totel blood volume for the porpoise may likenlse be relstively high.

The values for axgen eapacity of man, oxen, a rabbit, a horse, and a sheep were reported by Haldane and Smith (1899-1900). These values are given in Table VIII. An apparatus was desoribed by Barereft and Haldane (1902) In which they state oxygen eapacity of the blood can be determined manonetrieally with as little as $1.0 \mathrm{cc}$. of blood. Theyreport a difference in axygen cepacity of only 0.04 and 0.05 volume per cent for the ox and the cat, respectively, with their method in comparison with the carbon monoxide method.

\section{Present Day Mothods}

Van Slyke Method

A manometric apparatus for the deternination of oxysen capacity was described by Van S1yke (1918). Van S1yke and Stadie (1921) reported 
a 0.92 volumes per cent higher mean value for expgen capacity otudied in 5 men with the Van SIjke apparatus than with the carbon monoxide method. The Van SIyke method of doterrining exygen capacity has been used alnost universally since 1921.

\section{Roughton-Scholander Syringe Y Yethod}

A mloro-method whereby only 39.3 ans. of blood are needed for an axygen eapacity determination was described by Roughton and Scholander (1943). The deteraination is carried out in a 1.0 cubie centineter syringe with a fused capillary attached to the syringe. They report an average discrepancy for 3 minutes of only 0.05 volumes per cent with their method In comparison with the Van SIyike method. Grant (1947) modifled the syringe method so that aeration of the blood sample could be comploted within the syringe. In a study of 6 dogs, he reports the same mean values by means of the micro-sethod as obtalned by use of the Van SIylke apparatus.

With relation to the size of the blood sample needed for a determination, Roughton and Scholander's syringe method is very adaptable to study oxygen eapecity in mall animals. The procedure involves the delivery of 39.3 cubic mlllimeters of blood into the syringe by a pipette (FIg. 1) where the blood is inxed with physiological saline solution. Fig. 2 shows the transfor of blood under seline solution from the pipette to the capillarys in $A$, the pipette contalning the blood is fitted into the bottom of the cup of the capillarys in B, the blood has been withdram Into the syringe by withdrawal of the plungers in $\mathrm{C}$, the saline solution 1s drawn into the syringe on top of the blood. Aeration of the blood sample is accomplished by turning the syringe on its horizontal axis for 


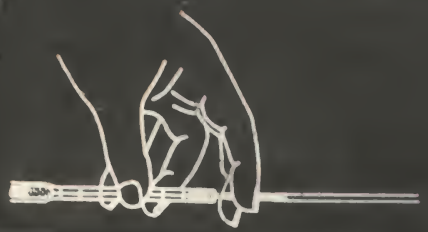

Fig. I

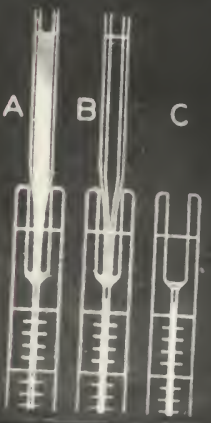

FIg. 2 
5 mimutes with an occasional turn at right angles. Once a minute during the earation, the afr supply is replenished. Then a solution contal ning potsesium ferricyanide, potassium bicarbonate, and saponin is introduced Into the syringe. The ferricyanide converts the hemoglobin to methimeglobin or reduced hemoglobin, and in doing so, releases the gases oxygen, nitrogen, and carbon monoxide. The bicarbonate supplies the carbon diaride in which the gases from the bl.ood are taken up, and the saponin lakes the red blood cells. A buffer solution containing sodium acetate and glacial scetic acld 18 added to the syringe which acts to keep the plit constant when the alkalles are later added. Urea 18 added to the syringe because of 1 ts protein dissolving ability. After the acetate buffer and urea solution is added, the mixture in the syringe is shaken (F1g. 3) to evolve the gases fron the blood. Inen sodiun hydrexide 18 added to absorb the carbon dioxide as ahown $\ln \mathrm{FIg}$. 4 ( $\mathrm{A}$, before absorption, $\mathrm{B}$, after absorption). Alkaline pyrogallol is then added to absorb the axygen. Tewperature equilibration is carried out at room temperature in beaker of water, before and after the pyrogallal is added, as shown in F/g. 5. The difference in readings of the divisions on the capillary of the syringe before and after the introduction of the pyrogallal represents the corgen capacity of the blood.

A detalled procedure followed by the author for the axysen eapacity investigation is outilined in Appendices VI, VII, VIII, and IX.

Oxysen Capacity Determinations of the Present Investigation with the Syringe Method

The author determined the oxygen capacity per undt of blood of 43 


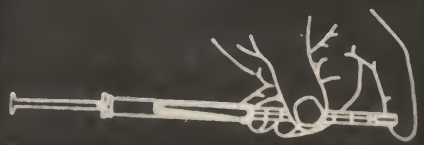

Fig. 3
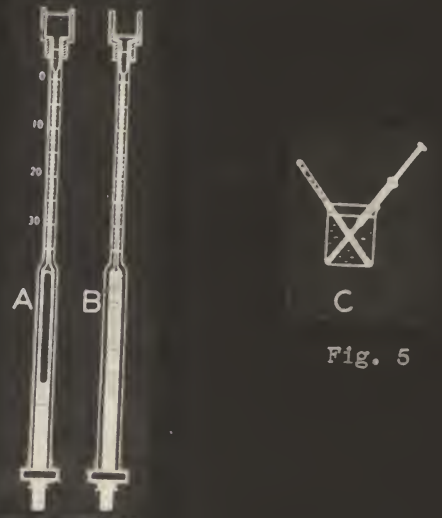

Fig. 5

Fig. 4 
mamals by the Roughton-Seholander syringe method. The mannals invertigated were: 20 albino rate (Rattus norvegicus), 3 cottan mice (Peromyscus gosaypimus), 3 Florids wood rats (Neotoms Maridans), 3 domert1eated guinea pigs (Cavla sp.), 7 galden hamsters (Cricetus auratus), and 7 bate (yyotis austroriparius). The data obtal ned in this study are presented in Table VII.

The albino rats were laboratory raised. Their body weights ranged from 7 to 302 grams. The rat weighing $7 \mathrm{gm}$. had an oxyzen eapacity of 5.3 volumes per cent. This rat was 5 dajs old at the tise of the cay gen capacity determination. In rats with greater body weight, the oxygen capacity of the blood was greater as shown in the table. The mean cygen capacity of 8 rats with a mean weight of 249 gas. was 18.1 volumes per eent.

Soune data are avallable in regard to the number of red blood celle and the amount of henoglobin per unit volune in rats of different ages. The red blood cell count of 162 rats from 1 to 8 days of age was 2,000,000 per can, according to Reich and Dunning (1943). Gardner (1947) reports that "the average number of red blood cells in the adult rat, regardless of sex or strain, is 8,520,000 per amn." She also reports that the henoglobin content of the blood of young rats averages $11.8 \mathrm{gm}$. per $100 \mathrm{cc}$. while the hemoglobin content of the blood of an achult rat averages 14.4 gm. per $100 \mathrm{cc}$. From these data it may be inferred that the rat with the least number of red blood cells present in the body has less hemoglobin to combine with oxygen, and consequently, the oxygen espacity per unit of blood for that animal is less than for an adult rat which has approcinately 
TABLE VIT

Oxygen Capacity of Aninals Dotermined in this Imvestigation

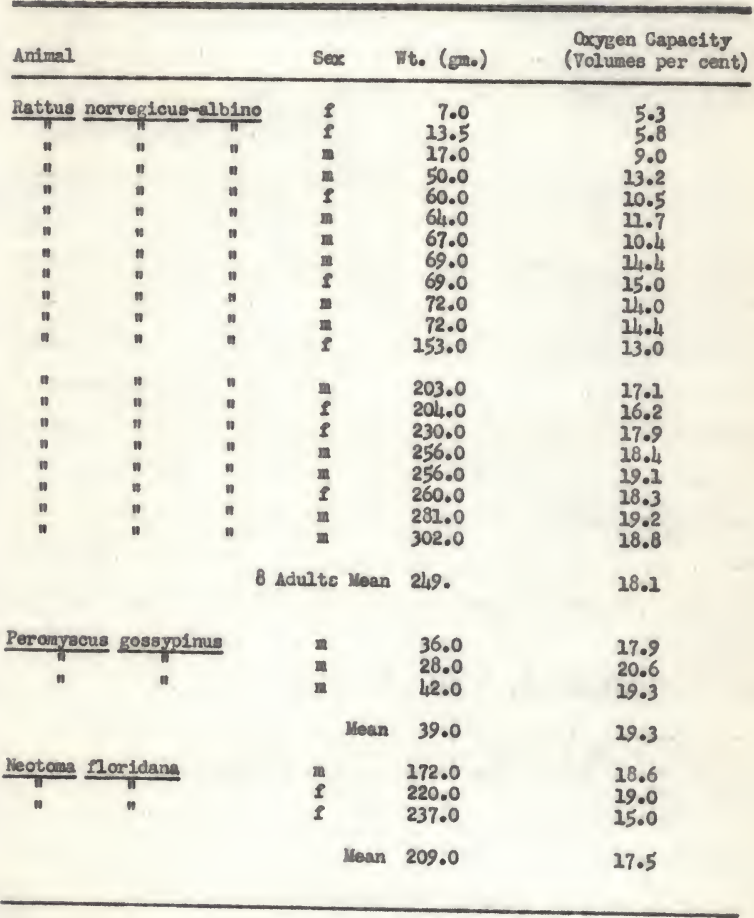




\section{TABLE VII (Contimued)}

Oxygen Capacity of Animals Deternined in this Investigation

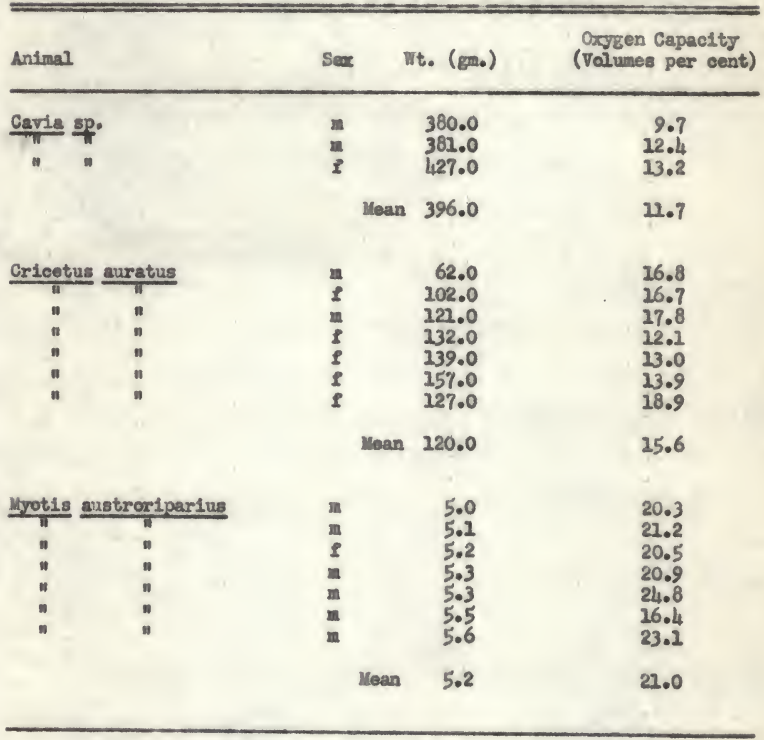


4 times the number of red blood colls present. It may be seen in Table VII that the oxygen capacity in volumes per cent increases as the welght of the rat 1ncreases.

The 3 cotton mice and 3 wood rats, in which the oxygen capacity of the blood was determined, were achults and had been in captivity for at least 2 years.

The cxygen capacity of the blood of 7 bate was deterwined on February 22, 1952, the day after they wore eaptured.

Blood for axygen apseity determinations was collected from the tail of the large albino rata. The tail was clipped, and drops of blood were collected in a parafrin block. In the ase of the other aninals, except the bats, blood was taken from the heart with a heparinised syringe and $3 / 4$ in. no. 24 needle. With the bats, blood was sucked directly into the pipette from the incised heart.

\section{Oasgen Capacity Values from Avallable Sources}

The manometric method of Van S1yke (1918) has persisted in use today because of 1 ts simplialty of operation and accuracy in repeated detexminations. However, other methods such as the syringe, henoglobin, spectroscope, and copper sulfate-speciflc gravity methods give comparable results with the Van SIyise method as shown in Table VIII.

It may be seen fron Table VIII that the carbon monordde and the Bancroft manometric methods give comperable revults in cate (Barcroft, 1902). Roughton and Scholander (1943) obtained practically the sane 
results in $\operatorname{man}$ with the syringe and Van SIyke methods. In opossums, almost the sane values were obtained by the author, using the henoglobin as the values reparted by Seott (1938) who used the Van S2yke method. No comparative evalustions for the spectroscope and copper sulfate-specifle gravity methods are avallable.

In Table VIII an asterisk is placed beside the values which appear valld. For the resson stated above, the spectroscope and copper sulfate-specirle gravity methods are Indicated by "?". 
TABLE VIII

Oxygen Capacity in Volumes Per Cent

\begin{tabular}{lll} 
ORDIR \\
Family No. Capacity Method Authority \\
\hline
\end{tabular}

MARSUPTALIA

Didelphidee

Didelphis virginiana piers $23 * 14.9$ Van SIyke Seott-1938

Didelphis Virginiana pigx 21 \#15.0 Hemoglobln Burke

CKTROPTERA

Vespert1lionidae

Syotis austroriparivs 7 .21.0 Syringe Burke PRIMATES

Hondnidae

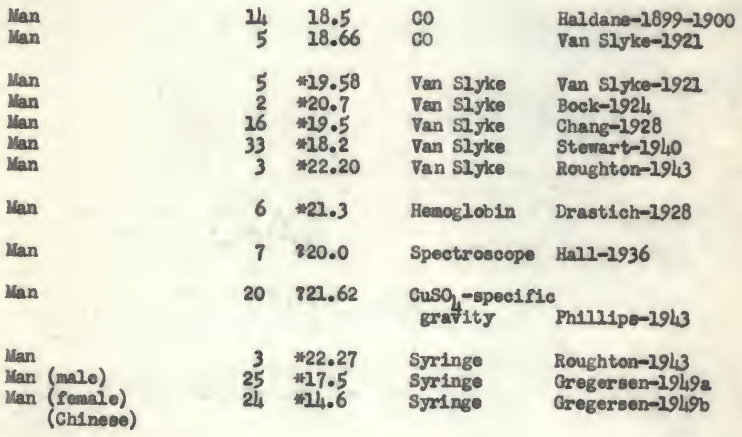


TABLS VIII (Continued)

Oxgrgen Capacity in Volumes Per Cent

\begin{tabular}{l} 
ORDER \\
Fantly \\
\hline
\end{tabular}

LMONORPHA

Ieparidae

\begin{tabular}{|c|c|c|c|c|}
\hline Rabb1t & 1 & 14.58 & co & Hal dane-1899-2900 \\
\hline Rabblt & 22 & 13.6 & 60 & Boyeott -1909 \\
\hline Rabbit (nale) & 4 & 25.95 & co & Salvensen-1919 \\
\hline Rabbit ( femaie) & 2 & 9.97 & $\mathrm{co}$ & Salvensen-1929 \\
\hline $\begin{array}{l}\text { Rabbit } \\
\text { Rabbit }\end{array}$ & 3 & $=15.4$ & Hemoglobin & Drastich-1928 \\
\hline Rabbit & 2 & $=27.6$ & Hemoglobin & Burke \\
\hline Rabb1t & 4 & 815.6 & Spectroseope & HaII-1936 \\
\hline
\end{tabular}

RODENTA

Seluridee

Woodehuek

$1120.7 \quad 60$

Rasmussen-1915

Castoridae

Beaver

$6 * 17.7$ Van slyke

Irving-2939

Cricetidac

\begin{tabular}{|c|c|c|c|c|}
\hline Cricotus auratus & 7 & *25.6 & Syringe & Burlese \\
\hline Maskat & 3 & $\approx 25.0$ & Van slyke & Irv1ng-1939 \\
\hline Percanscus gossypi mas & 3 & *19.3 & Syringe & Burles \\
\hline Neotoma floridana & 3 & - 17.5 & Syringe & Burke \\
\hline
\end{tabular}

Muridae

\begin{tabular}{|c|c|c|c|c|}
\hline Mee & 6 & $* 29.1$ & Heanoglobin & Drast1ch-1928 \\
\hline$\frac{\text { Rattus norvegicus }}{\text { (albino, }>200}$ & 8 & & & \\
\hline
\end{tabular}




\section{TABLEE VIII (Continued)}

Oxygen Capacity in Volumes Per Cent

\section{ORDER}

Fanily

No. Capacit ty Method

Authorlty

Rattus norvegicus

(2lbino, $<200$ gm.) $12 \quad 11.3$ Syringe Burike

Cartidae

Cavia sp.

3 *21.7 Syringe

Burke

Chinohillidse

Viscach (Lagostomus) 2 I15.8 Spectroscope Hall-2936

CARITVRA

Canidee

\begin{tabular}{|c|c|c|c|c|}
\hline Vulpes fulva & 1 & $\approx 21.0$ & Van SIyke & Irv1ng-1939 \\
\hline Dog & 2 & 23.6 & co & Jolyot-1896-97 \\
\hline $\begin{array}{l}\text { Dog } \\
\text { Dog }\end{array}$ & $\begin{array}{l}2 \\
1\end{array}$ & $\begin{array}{l}* 15.2 \\
* 26.7\end{array}$ & $\begin{array}{l}\text { Hemoglob1n } \\
\text { Hemoglobin }\end{array}$ & $\begin{array}{l}\text { Drastich-1928 } \\
\text { Burke }\end{array}$ \\
\hline Dog & 6 & $\# 15.77$ & Van SIyke & Grant-1947 \\
\hline Dog & 6 & $* 15.80$ & Syringe & Orant-1947 \\
\hline
\end{tabular}

Proeyonidae

Procyon lotor eluous 2 \$15.7 Henoglobin Burke Felidae

$\begin{array}{lccll}\text { Cat } & 1 & 12.25 & 60 & \text { Bareroft-1902 } \\ \text { Cat } & 1 & 12.20 & \text { Barerort } & \text { Bareroft-1902 } \\ \text { Cat } & 2 & * 15.0 & \text { Hemoglobin } & \text { Drastich-1928 }\end{array}$


TABLIE VIII (Continued)

Cxyren Gapacity in Volunes Per Cent

ORDIRR

Fanily

Oxygen

110. Capacity Nethod

Authorelty

Mustelidae

Mustela vison

22 \$23.9 Van S1 yike

Scott-2939

Martes americans

2 .24.3 Van S1yke

Scott-1939

Otarildae

Stellex': Sea IIon

1 *29.8 Van SIyke

Florkin-1932

Phocldae

Phoca vitulina

11 *29.3 Van SIylse

Irving-1935

\section{CERACEA}

Phocsentdase

\begin{tabular}{|c|c|c|c|c|}
\hline Porpolae & 1 & 30.9 & co & Jolyet-1896-97 \\
\hline $\begin{array}{l}\text { Porpolse } \\
\text { Porpolse }\end{array}$ & $\frac{2}{2}$ & $\begin{array}{r}842.5 \\
\approx 22.2\end{array}$ & $\begin{array}{l}\text { Van slyike } \\
\text { Van Slylce }\end{array}$ & $\begin{array}{l}\text { Sudrulki-1924 } \\
\text { Qreen-1933 }\end{array}$ \\
\hline Porpolse & 6 & $=19.0$ & Henoglobln & Drast1ch-1928 \\
\hline
\end{tabular}

Delphintdae

Tursiops tursio

Tursiops truncatus

Physeteridae

Physeter macrocephalus I $29.09 \mathrm{CO}$

Balsenopteridae

Blue and $\mathrm{M}$ n Whales
233.460

1 *19.1 Hemoglobin
Jollet-1902

Eichelberger-1939 
TABLE VIII (Continued)

Oagysen Capacity In Volumes Por Cent

\begin{tabular}{ll}
\hline OROBR \\
Fanily & Mocyzen \\
Capacity Method Authority
\end{tabular}

\section{PERISSODACTITA}

Equidee

$\begin{array}{lllll}\text { Horse } & 2 & 18.39 & 60 & \text { Haldane-1899-1900 } \\ \text { Hores } & 3 & \text { wh.2 } & \text { Henoglobin } & \text { Draarich-1928 }\end{array}$

ARTIODACTILA

Susdee

P1g $10 * 14.9$ Henoglobin Burke

Gamellidae

Llama husnachus glang $4 \quad 323.5$ Spectroscope Hall-2936

Llans vicugns 1 817.5 Spectroscope Hall-1936

Borldae

\begin{tabular}{|c|c|c|c|c|}
\hline $\begin{array}{l}0 x \\
0 x \\
0 x\end{array}$ & $\begin{array}{l}6 \\
1 \\
5\end{array}$ & $\begin{array}{l}18.12 \\
19.70 \\
27.5\end{array}$ & $\begin{array}{l}\text { CO } \\
\text { CO } \\
\text { CO }\end{array}$ & $\begin{array}{l}\text { Haldane-1899-1900 } \\
\text { Bareroft-1902 } \\
\text { Abeloos-1928 }\end{array}$ \\
\hline$d x$ & 1 & 29.74 & Barcroft & Bararoft-1902 \\
\hline $\begin{array}{l}0 x \\
0 x\end{array}$ & $\frac{2}{5}$ & $\begin{array}{l}* 23.53 \\
* 28.6\end{array}$ & $\begin{array}{l}\text { Van Slykeo } \\
\text { Van Slyke }\end{array}$ & $\begin{array}{l}\text { Van s1yke-1928 } \\
\text { Abelooe-1928 }\end{array}$ \\
\hline Cow & 2 & $* 24.7$ & Hemoglobin & Drastich-1928 \\
\hline $\begin{array}{l}\text { Sheep } \\
\text { Sheep }\end{array}$ & $\frac{1}{3}$ & $\begin{array}{l}17.30 \\
16.2\end{array}$ & $\begin{array}{l}\mathrm{co} \\
\infty\end{array}$ & $\begin{array}{l}\text { Haldane-1899-2900 } \\
\text { Abeloos-2928 }\end{array}$ \\
\hline Sheep & 1 & *15.8 & Henoglobin & Drast1ch-1928 \\
\hline $\begin{array}{l}\text { Sheep } \\
\text { Sheep }\end{array}$ & นพื & $\begin{array}{l}=17.5 \\
=14.98\end{array}$ & $\begin{array}{l}\text { Van slyke } \\
\text { Van slykse }\end{array}$ & $\begin{array}{l}\text { Abeloos-1928 } \\
\text { Baker-1933 }\end{array}$ \\
\hline
\end{tabular}


TABLE VIII (Continued)

Cosygen Capacity in Volumes Per Cent

\begin{tabular}{|c|c|c|c|c|}
\hline $\begin{array}{l}\text { ORDER } \\
\text { Fantly }\end{array}$ & No. & $\begin{array}{l}\text { Oxygen } \\
\text { Gapacity }\end{array}$ & Method & Authority \\
\hline Sheep & 5 & 215.9 & Spectroseope & Ha21-1936 \\
\hline $\begin{array}{l}\text { Lamb (birth) } \\
\text { Lamb (1 nonth) }\end{array}$ & $\frac{4}{4}$ & $\begin{array}{l}-20.5 \\
-27.2\end{array}$ & $\begin{array}{l}\text { Van slyke } \\
\text { Van slyke }\end{array}$ & $\begin{array}{l}\text { Cotsev-1939 } \\
\text { Cotsev-1939 }\end{array}$ \\
\hline $\begin{array}{l}\text { Goat (nale) } \\
\text { Goat (femalo) }\end{array}$ & $\begin{array}{l}1 \\
3\end{array}$ & $\begin{array}{l}14.8 \\
-12.1\end{array}$ & $\begin{array}{l}\text { Hemoglobin } \\
\text { Hemoglobin }\end{array}$ & $\begin{array}{l}\text { Drastich }-1928 \\
\text { Drast1ch-1928 }\end{array}$ \\
\hline Goat (2 days) & 4 & 1121.4 & Van SIyike & k110tt-1934 \\
\hline
\end{tabular}




\section{TABLE IX}

Quygen Capacity in Varlous Kammals as Determined by Acceptable Methods

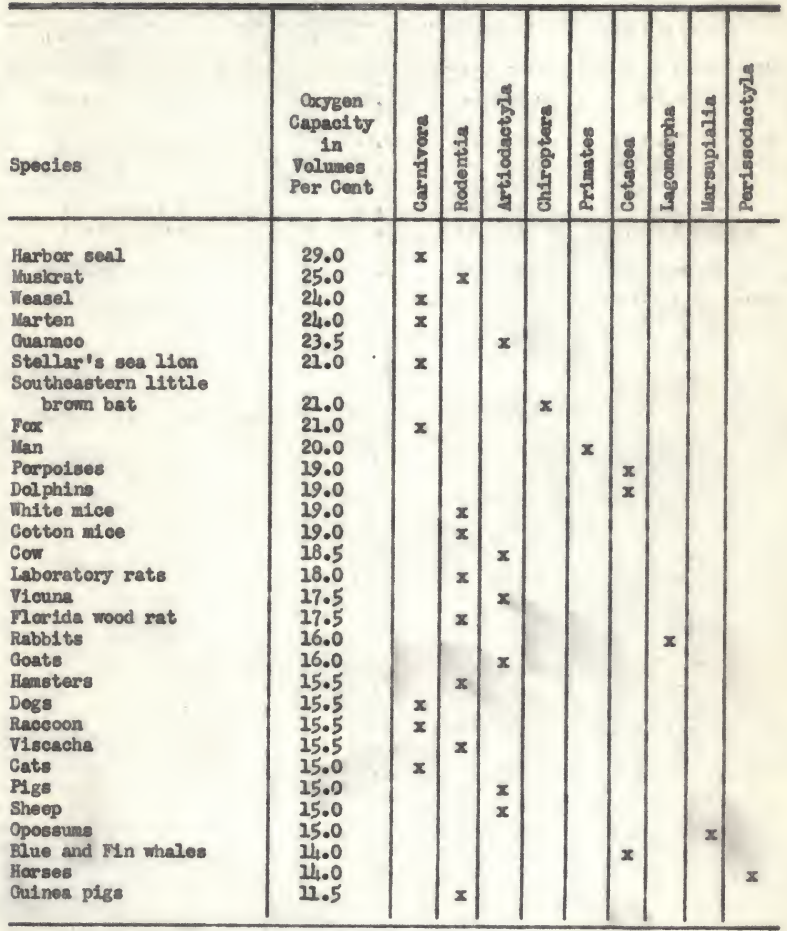




\section{SUMAURY AND CONCLUSIONS}

This study was undertaken to detemine blood volume and acygen capacity in manmals by the use of various tochndques.

small, and aupposedly young, Individuals of a species have a greater blood volume per unit of body weight then adults as demonstrated with swine and opossums. In swine the blood volume values decreases from an average of $10.5 \mathrm{mll}$. per $100 \mathrm{gm}$. at 1000 to $2000 \mathrm{gm}$. of body weight to $6.0 \mathrm{ml}$. at $96,000 \mathrm{gm}$. Opossums exchib1t the same relation of a decrease in blood volune per unit weight to an increase in body weight as swine although the relationship is not as pronounced. No differences of blood volume whth regard to sex are apparent.

Values determined by acceptable methods complled from Table VI of blood volume for opossums are 5.5, 6.0 for sheep, 6.5 for rabbits, 7.0 for laborstory rats, 7.2 for horses, 7.5 for man and awine, and 9.0 for dogs, in milliliters of blood per $100 \mathrm{gm}$. of body weight. It is evident froa these values that blood volume in adulta in relation to sise, we1ght, or texononic groups is comparable.

Thorough alxing of the T-1824 dye and P-32 labelled red blood cells was effected in one mimite in the blood of opossums and by 10 minutes in the blood of swine.

The dye and P-32 in opossums and ow1ne decreased with tine until at 48 hours there was no measurable anount of dye present, and 13.8 and 23.0 per cent of P-32 remal ned, respectively. 
In 21 opossums mean values for red blood cell count, henoglobin, and rectal temperatures are 5,280,000 per cm., 21.1 gme per 100 cc., and $35.1^{\circ} \mathrm{C}$. , respectively. In 20 swine the mean value for red blood cell count is $7,070,000$, and is 11.0 grans of hemoglobin per 200 ce. of blood.

Oxyzen capacity per unit of blood is less for young animals than adults as denonstrated in this investigation with laborstory rats. The values range fron 5.3 for a 5 day old animal to 19.2 volumes per cent for an adult.

It is diffloult to make comparative evaluations for the different mamels listed in Table $\mathrm{Ix}$, whlch was complled from values in Table VIII, Inasmich as data for age, weight, and sex are not reported in most cases.

In considering the data in Table IX from a taxonoaic viewpolnt, It is evident that the differences in values are not on an ordinal basis. Nor are these differences due to sise as shown by values given for the muskerat, weasel, and martan which possess an cxygen capacity that is very different from that of the opossum, although all of these anials are of about the sane arse. Also large animals, as Illustrated by horses and harbor seals, possess great differences in oxygen capacity values. The axygen capacity of animals in the same fanily, wuch as dogs. and foxes, is very different. It is also noted that there is a great difference in the oxygen eapacity of diving namals. For instanee, the 
exygen eapacity of blue and fin whales is very different from that of harbor seals and Stellar's sea lions.

Frow the information at hand, it appears that values for exygen capacity vary with the specius. 


\section{ACKNOWLADGMEYTS}

I would like to express my appreciation to the people who have alded me in this imvestigation. I extend gry gratitude to Dr. H. B. Sherman, chaiman of ay combittee, who has guided me in wy research program and who has given freely his time and advice thenever needed. I would also like to thank the othar nembers of ny connitteo for their help and advice - Dr. E. Ruffin Jones, Jr., Dr. Plerce Erodkorb, Dr. Lowis Berner, who served as ny combltee chalrean during the sumner of 1951, and Dr. Ceorge K. Davis of the Department of Animal Autrition, College of Agriculture.

I would also like to thank Dr. Davis for suggesting the use of radloactive phosphorus-32, for provlding the 1sotope, the laboratory space and equipnent used, the eare and malntenance of the animals in the blood volume study, and for injecting and withdrawing labelled blood In the ear vein of a plg. My appreciation is also extended to Dr. Ray L. Shirley, formerly associated whth the Department of Animal Nutrition, who alded in instructing in the use and mothods of radosetivity. Ir. John T. MoCall and Ir. Marshall Mirenburg, laboratory teohnielans at the Nhtrition Laboratory, alded greatly in handling the aninals.

I would like to express ny gratltude to the Department of Blalogy for the appointment of graduate and teaching assiatantships without which this investigation could not have been carried out. I would also Iike to thark the department for the geserosity wlth whlch equipment was 
provided and for the purchase of 20 opossums.

I would like to thank the several people who have contributod antmals for this study. Dr. H. D. Wallace provided the guines pigs and swine; Dr. Blbert Voss, of the Department of Pharmacology, provided a dog; Dr. John D. KIlby contributed 3 oposauns, Dr. George H. Pournelle provided me with the cotton mice; Irr. Panl Pearson provlded the Florida wood rats; Nir. Robert Cuming gave me the bats used; Mr. Edward Joseph provided the raccoon; and IIr. L. R. Arrington provided the rabbits. Lfy aincere thanks are due to Lr. Julian J. Baumel tho alded me In the statistical ovaluation of the data in regard to the pigs. Figures 1, 2, 3, 4, and 5 were copied and rearranged srom Roughton and Scholander (1943). 


\section{LTTEATURE CITED}

Abeloos, M., Bareroft J., Cordero, N., Harrison, T. R., and Sendroy, J., Jr.

1928 The measurement of the $\mathrm{O}_{2}$ eapacity of haenoglobin. J. Physlol. $66: 262-266$.

Atlrawa, J. K.

1950 Muid volume and electrolyte concentrations in nornal rabbits. Am. J. Physiol. 162:695-702.

Anderson, R. S.

1942 The use of radio active phosphorus for determining circulating erythrocytes volume. Am. J. Physiol. 1378 539-43.

Arnold, H. R., Carrier, B. B., Sndth, H. P., and Whipple, G. H.

1921 Blood volume studies. V. An. J. Physial. 56: 313-327.

Asmassen, $\mathrm{E}$.

1942 On the determination of the blood volume by the comethod. Acte Phrolol. Seand. 3: 156-163.

Baker, D. W.

1933 The blood of sheep. Ph. D. Thesis. Cornell UnIv., pp. 74-75.

Bakwin, H., and Rivkin, $\mathrm{H}_{0}$

1924 The estimation of the volume of blood in noraal Infants and in infants with severe malnutrition. Am. J. Dis. Child. 278 $340-351$.

Barbour, H. G.

1921 The heat regulating aechaniam of the body. Physiol. Rev. 1. 295-307.

Bareroft, J., and Gotsey, T.

1937 Acquisition of blood by the foetus from the placenta at birth. J. Physlol. $90.27 \mathrm{p}$.

Bareroft, J., and Haldane, J. S.

$1902 \mathrm{~A}$ method of estimating the $\mathrm{O}_{2}$ and carbonic acid in mall quantities of blood. J. Phrsiol. 28: 331-343.

Bareroft, J., Kennedy, J. A., and Mason, M. F.

1939 The blood volume and kindred properties in pregnant sheep. J. Physiol. $95,159-172$.

Barlow, O. W., and Whitehead, R. W.

1929 A comparison of the body welghts, erythrocyte counts, and total blood volumes of nornal, beri-beri, and fasting rats. The inIluenoe of lactose, mineral ofl, and magnesium carbonate on 
the aneail of rice disease. Amer. J. Physiol. 89:5460-554.

Barratt, J. O. W., and Yorke, W.

1909 A method of eatimating the total volune of blood contained in the living body. Roy. Soc. London. Proc. 81: 381-384.

Basett, H. C., Sunderman, F. W., Doupe, J., and Scott, J. C.

2940 climatic effects on the volume and composition of blood in aan. Am. J. Phroiol. 129: 69-83.

Beckwith, J. R., and Chanutin, A.

194 Blood volumes in hypertonsive partially nephreetomitsed rats. Proc. Soc. Fxper. B10l. and Med. 46: 66m.

Bend1tt, B. P., Straube, R. L., and Humphreys, B. I.

1946 The deteruination of total circulating serve protelns and erythrocyte volunes in normal and protein deploted rets. Proc. Soc. B. B. B101. and Med. 628 189-192.

Beri in, N. I., thuff, R. L., Van Dyke, D. D., and Hennessy, T. G. 1949 The blood volune of the adult rat, as detern Ined by 5059 and p32 labelled red oells. Proc. Soc. Bxper. Blol. and Med.

* 72 (2): $176-278$.

B1schorf, T. L. W.

1856 Bestimmung der Blutmenge bel einem Hilngerrichten. Zeltschr. f. W1ssenseh. 2001. $72331-338$.

Bock, A. V.

1921 The constancy of the volume of the blood plasma. Arch. Int. Med. 27, 83-201.

Bock, A. V., Vancaulaert, C., D1II, D. B., Folll1ng, A., and Hurxthel, L. If. 1928 Studies in muscular activity. III. Dynanicel changes ooourring in man at work. J. Physiol. 66: 136-161.

Bonnycastle, D. D.

1947 Repeated determinations of plasms volumes, bloed voluraes, and total avallable fluid in a group of normal trained dogs. Amer. J. Physiol. 151 (2): 504,-508.

Bonnyeastle, D. D., and Cleghorn, R. A.

1942 A study on the blood volume of a group of untralned normal dogs. Am. J. Phys107. 137: 380-383.

Boycott, $\Lambda_{0}$..

1913 On the regulation of the blood volume in normal and nephritic animals. J. Path. and Bact. 18: 11-31. 
Boyeott, A. E.

1912 The sise and grourth of the blood in rabbits. J. Path. and Bact. 16: 485-501.

Boyeott, A. E., and Ch1solm, R. A.

1912 The influence of undorfeeding on the blood. J. Path. and Bact. 16: 263-268.

Boycott, A. E., and Douglas, C. G.

1909 On the $\mathrm{CO}$ mothod of determining the total $\mathrm{O}_{2}$ apacity and volume of blood in animals, id th some experinents on anaenta and transfusion. J. Path. and Bact. 13: 256-281.

Brednow, w.

1931. Beelnflussung der sirkllerenden Blutienge und der Blutvertellung dureh physikellsche und pharneakolog 1 sche Massnahmen. Zoitsohrift fur die gesante experimentelle Medisin. 78, 177192.

Brines, J. K., Gibson, J. G., 2nd, and Kunkel, P.

2941 Blood volune in nornal infants and children. J. Pedist. 18: $447-457$.

Bull, S., and Carroll, W. E.

1937 Prlnaiples of feoding farm animalg. Macinillan Co., New York. Revised बd. $395 \mathrm{pp}$.

Burke, J. D., Sh1rley, R. L., and Davis, O. X.

1951 Blood volume in sidne as determined by radio-phosphorus. Anat. Ree. 211: 448.

Caupbell, W. N., Solcul chuk, A., and Peaman, E.

1948 Validity of $\mathrm{I}-182 \mathrm{~h}$ in pleame volume determinations in the human. Amer. J. Physiol. $152(3): 563-566$.

Cartland, G. F., and Koch, C.

1928 A nero-nodifleation of the Kelth-ilowntree plasma dye method for the estination of blood volume in the rat. 쇼. J. Physiol. 85. $540-545$.

Chang, H. C., and Harrod, G. A., Jr.

1928 The determination of the eirculating blood rolume with $\mathrm{CO}$. J. Clin. Invest. 5: 393-405.

Chisolm, R. A.

1913 On the sise and growth of the blood in tame rats. Quart. J. Dxper. Physiol. 4: 207-229. 
Cohneteln, J., and Zuntz, N.

1884 Untersuchungen uber das Blut, den Kre1alauf und dio Atmang bein Sangetheir-Foetus. Pnugers Arehiv. 34: 173-233.

Colin, s.

1873 Traité de Physiologie oomparé des animaux (par.). Parls.

Gourtice, F. C.

1943 The blood volume of normal antmals. J. Physiol. 102, 290305.

Courtice, F. C., and Cunton, R. W.

1949a The determination of the blood rolume in man by the $\mathrm{CO}$ and dye methode. J. Phys101. 108, $142-156$.

Courtice, F. G., and Gunton, R. W.

$294 \%$ The determination of B.. . by $\mathrm{CO}$ and dye (T-1824) methods in rabbits. J. Physiol. 108:405-427.

Crooke, A. C., and Morris, C. J. O.

1942 The determination of plasma volume by the Evans blue method. J. Phyz10i. 101: 217-223.

Cruickshank, E. W. H.

1926 On the output of haenoglobin and blood by the spleen. $\mathrm{J}$. Physiol. 61: 455-464.

Cruickshank, E. W. H., and Whiterfleld, I. C.

1945 The behavior of $\mathrm{T}-1824$ (IVans bluo) in circulating blood and a modified method for the estimation of plasma volume. J. Phyaiol. 104: 52-59.

Crus, W. O., da Sliver, E. Mo, and de Mello, R. P.

1945 Dados henatolog1cos do cao advito normal. Men. Inst. Oswraldo Crux. 42: 609-628.

Culbertson, J. T.

1934 The determination of the plasma volune and the blood rolume of the rabbit by the injection of homalogous anti-crystallisedegg-albunin-servm. Am. J. Physiol. 107: 120-127.

Darrow, D. C., Soulle, H. C., and Buckmen, T. E.

1928 Blood volume in norral infants. J. Clin, Invest. 5: 243-258.

Davis, J. 8.

2940 Blood volune in cobalt polyoythemia. Broe. Soc. Bxper. B10l. and Med. 45: 672-673.

Davis, L. J.

1942 Determination of blood volune In man with Bvans (T-1824). Dye. Edinburgh ‥ J. 49: 4,65-4,83. 
Dawson, A. B., Evans, H. Y., and Whipple, G. H.

1920 IIf. Behavior of large serles of dyes introdueed into the circulating blood. Am. J. Physiol. 51: 232-256.

Dleckmann, W. M०, and Wogner, C. I.

1934 The blood in normal pregnaney. I. Blood and plasma rolumes. srch. Int. Yed. 53: $71-86$.

Douglas, C. G.

1906 A method for the determination of the blood volume in animals. J. Physiol. 33: 493-505.

Douglas, C. C.

$1910^{\circ}$ The determination of the total axygen capacity and blood volune at different altiltudes by the $\mathrm{CO}$ method. J. Physiol. 40, 472477 .

Drastich, L.

1928 Ist die Konsentration des Blutfarbstoffes in Blutkorperchen bel allen Tleren konstant? Pflugers Archiv fur die gesante Physiologie. Bd. 219: 227-232.

Dreyer, G., and Ray, W.

2910 III. The blood volume of mamnals as determined bJ experiments upon rabbits, g. pigs, and mices and its relation to the body weight and to the surface area expressed in a formuls. Phit?. Iran. Ror. Soc. of London. Ser. B. 101: 133-260.

Dreyez, C., Ray, W., and Walker, E. W. A.

1913 On the blood volune of warm blooded animals; together with an inguiry into the value of some results obtained by the $\mathrm{CO}$ wethod in health and disesse. Skandin. Areh. Physiol. 28, 299-324.

Dukes, H. H.

1937 The physiology of domestic animals. Comstock Publiahing Co., Ithaca, 1. 1. 1.695 pp.

Eichelberger, L., Fetcher, E. S., Gelling, L. K. K., and Vos, B. J.

1939 Nuscle and blood hemoglobin in the dolphin. Solence 90: 443.

millott, R. Ho, Hall, F. G., and Haggett, A. St. G.

1934 The blood volume and $\mathrm{O}_{2}$ capacity of the foetal blood in the goat. J. Physlal. 82 i 160-171.

Mrlanger, $J$.

1921 Blood volume and 1ts regulation. Phrsiol. Rev. 1s 277-207.

Evans, G.

1942 Deamination of DImalanine in the adrenalectomised rat. Endocrinology 29: 737-739. 
Evans; W. $\Lambda_{0}, J_{0}$, and Gibson, J. G., 2nd

1937 Blood volume in diuresis. An. J. Physel. 118: 251-259.

Ferrebee, J. W., Beclliner, R. W., and LeLgh, O. C.

1941 Passage of the blue dye T-1824 fron the blood strean into the 1yuph. Proc. Soc. Exper. B101. and Med. 46: 549-553.

Fine, J., and Sellgman, A. $M_{0}$

1943 Traumat1c shock. IV. A study of the problem of the wloot plasma" in heacorhagle shock by the use of radio active plasuna protein. J. clin. Invest. 22: 285-303.

Morkin, M., and Redereld, A. O.

1931 On the respiratory funotion of the blood of the sea 11on. B101. Bull. 61: 422-426.

Jranke, $E_{\bullet}$, and Benedict; S. R.

1920 A method for the determination of blood valume. J. Lab. and Clin. Hed. 6: 618-624.

Frledlander, $\mathbf{H}_{\text {, }}$ Laskey, $\mathrm{N}_{0}$, and SIIbert, S.

1936 Effeot of eatrogenic substance on blood volume. Fndocrinologr 20: $329-332$.

Fries, H.

1911 Dber Veranderungen der Blutmenge in der Schwangerschaft. Ztschr. I. Geburtsh. u. Gynak. 69: 340-345.

Turth, J., and Sobel, $H_{0}$

1946 Hyperrolemis secondary to grafted gramalose-cell tumor. J. Natl. Cancer Inst. 7; 103-113.

Gardner, Mary Va.

2947 The blood pieture of normal laborstery aninals. A revlew of the 11terature 1936-1946. J. Franklin Inst. 243 (1): 77-86.

Gelhorn, Alfred, Merrell, Margaret, Raulsin, Robert He

2944 The rate of transcaplilary exchange of sodim in noral and shooked dogs. An. J. Physiol. 142: 407-427.

Gibson, J. O., and

1941 Clinteal signifleance of blood volune. Ann. Int. Med. 14. $201 / 4-2026$.

Gibson, J. G., and Evans, W. A.

1937 I. Clinieal application of a method employlng the 120 dye "Bvans bIue" and the spectrophotoneter. J. Clin. Invest. 16: 301.

Gibson, J. G., and Dvans, W. A.

$1937 \mathrm{~b}$ II. The relation of plaama and total blood volume to venous pressure, blood valocity rate, physical measurements, age and sex in 90 normal humans. J. Clin. Invest. 16: 317-328. 
Q1bson, J. Q., and Bvelyn, K. A.

1938 Clinical studies of the blood volume. IV. Adaptation of the method to the photoeleetric mierocolorineter. J. Clin. Invest. 17. 1953-158.

Gibson, J. G., 2nd, and Gregersen, $M$. I.

1935 Toxicity of tro vital dyes used in plasma volume determinations. 스. J. Physiol. (Proc.) 113 i 50.

Gibson, J. G., Peacock, W. C., Sehrman, A. M., and Sack, A.

1946 C1rculating red cell valume measured simultaneously by the redio active Iron and dye methods. J. Clin. Invest. $25(6), 838 \mathrm{~m}-847$.

Gilder, H., lhuller, O. H., and Phillips, R. A.

1940 Hixing time of $\mathrm{T}-1824 \mathrm{~h}$ in blood. 스. J. Physiol. 129,362.

Cotsev, T.

1939 The blood volume in lambs. J. Phrgiol. 94: 539-54,9.

Govaerts, J., and Lambrechts, A.

1942 Etude sur le volume sanguin methode de mesure du valume ches 1 'home et le chien a l'aide du radiopyrosphore. Acta. Blologtea Belglea. 11. $425-428$.

Craff, S., and Clarke, H. T.

1932. Determination of plasana volume. I. The dye method. Arch. Int. Hed. $48,808-820$.

Grant, W. C.

1947 Determination of $\mathrm{O}_{2}$ eapacity on 39.3 cubic millimeters of blood. Proc. Soc. Bxptl. B10l. and Med. 66 (1), 60-62.

Oreen, A. A., and Redfleld, A. O.

1933 On the respiratory funetion of the blood of the porpoise. B1ol. Bu21. 64: $44-52$.

Aregersen, I. I.

1944 A practical mothod for the deterwination of blood volune with dye I-1824. J. Lab. and C11n. Yed. 29 (12), 1266-1286.

Oregersen, M. I.

1949 . Physiological characteristios of the Chinese. I. Plasma volume, blood volume, avallable fluid (NaSCN), hematocrit value, plasua protein leval and axygen oapacity and CO content of the blood in normal Chinese mal es. Chinese J. Physiel. 17: 47-72.

Gregersen, H. I.

1949b Physiolog1cal characteristics of the Chinese. II. Flasms volume, blood volune, available Ruld (NaSCM), hematoerit value, plasma protein level and expgen capacity and $C 0$ content of the blood in nornal Chinese fenal es. Chinese J. Physiol. 17: 73-07. 
Cregarsen, M. I., Oibson, J. J., and Stoad, E. A.

1935 Plasma volume determination with dyes: errors in colorimetrys use of the blue dye I-1824. Am. J. Phys101. 113: 54-55.

Oregersen, M. I., and Schiro, th.

1938 The behavior of the dje T-1824 with respect to 1 te absorption by R B C and its fate in blood undergoing coagulation. Am. J. Physiol. 121: 284 -292 .

Crehant, J. L., and Quinquand, $\mathrm{B}_{\bullet}$

2882 Mesure du volume de sang contenu dans l'organisme d'un manmifòre vivant. Compte rend. Acad. Se. 94: 1450-1460.

Corifrith, J. Q., Jx., and Campbell, R.

1937 i method for determining blood volume in rats. Proc. Soc. Bxper. Biol. and Med. 36:38-40.

Criffsth, J. Q., and Ingle, D. W.

1940 Blood volume in experimental hypertension following subtotal nephrectang. Proc. Soc. Exper. B101. and Yed. L4: 538-5h0.

Gruneberg, Hans

1942 The growth of the blood of the rueking mouse. J. Path. and Bact. $52(3): 323-329$.

Haecker, T. L.

1920 Investigations in beef productions. Minn. Agr. Bag. Sta. Bull. 193, pp. 2-211.

Hahn, P. F., Ross, J. F., Bale, W. F., Balfour, W. H., and whipple, G. H. 1942 Red ceil and plasna volume as determined by radio iron and by dye. J. Bxper. Ned. .75, 221-231.

Hahn, P. F., Balfour, W. H., Rosa, J. F., Bale, W. F., and Whipple, G. H. 1941 Red cell volume eirculating and total as deternined by radio Lron. Se1. 93: 87-88.

Hahn, L., and Hevesy, G.

1940 A method of blood volume determination. Acta. Phyriol. Scand. 1. 3-10.

Haldane, J., and Smith, J. L.

1899 The mass and $\mathrm{O}_{2}$ capactity of the blood in man. J. Physlol. 25: 331-343.

Hall, $\boldsymbol{F}, Q_{\text {. }}$

1936 The effect of altitude on the afrinity of hemoglobin for $\mathrm{O}_{2}$. J. B101. Chem. 115: 485-400. 
Hansard, S. L., Sauberllch, H. E., and Comar, C. L. 1951 Blood rolume of sinine. Proc. Soc. Bxper. B101. and Med. $78: 544-545$.

Harris, D. T.

1920 The value of the vital-red method as a clinical means for the estimation of the volume of the blood. Brit. J. Exper. Path. $1: 142-158$.

Harrington, C. Ro, Pochin, B. E., and Squire, J. H.

1940 A simplieation of the Bvans blue method of blood voluse determingtion. Clin. Sei. (formerly Heart) 4i 312-321.

Heohtner, 0 .

1945 Concerning the hypersensitivity of adrenalectonised rats to vascular stress. Indoorinology 36: 77-87.

Helssler, L.

1886 Zur Lehre von der Plethora. Arb. a. d. Path. Inst. su Munchen. Stuttgart. 322-349.

Hevesy, G., Koster, K. H., Soreneen, Q., Warburg, B., and Zerahn, K.

1943 The red corposcle content of the eirculating blood determined by labelling the erythrooytes with radiophosphorus. Act. Yod. Seand. 116:561-576.

Hevesy, G., and Zerahn, $\mathbf{X}$.

1942 Determination of the red corpusele content. Aot. Physiol. Seand. Li $376-384$.

Hบ1ㄱ, R. T.

1933 Blood volume in single and parablotic rats. Proc. Iowa Acad. Se1. $401236-238$.

Hooper, H. P., Staith, H. P., Belt, A. E., and Whipple, G. H.

1920 I. Experimental control of a dye blood volume method. N. J. Phyrial. 51: 205-220.

Hopper, J., Jr., Tabor, H., and winkler, $\Lambda_{*} \psi_{*}$

1944 Simultaneous measurements of the blood volune in man and dog by means of Brans blue dye and by means of Co. J. Clin. Invest. $23(5): 628-625$.

Irving, L.

1939 Regpiration in diving mamals. Physiol. Rev. 19: 112-134.

Irving, L., Solandt, O. M., Solandt, D. Y., and Fisher, K. C.

1935 Respiratory characterlstics of the blood of the seel. J. Cell. and Conp. Phrsiol. 6: 393-403. 
Jollot, $r$.

1902 Sur quelques conditíons de 1 'adaptation des mamnifères eétacós. VII. Soc. Soien. et Sta. B101. d'Areachon. pp.137-140.

Jolly, J., and Stint, J.

1905 Masse totale du sang ahes le rat blane. Campt. Rend. Soc. de B101. (Paris) 58: 835-837.

Jolyet, r., and Sellier, J.

1896 Contribution a l'6tude de la respiration du phoque. VIII. Soc. Scien. et Sta. Biol. d'Areachon. pp. 63-66.

KeIth, No M., Rowntree; L. G., and Gerachty, J. F.

2915 A mothod for the deternination of plasma and blood volume. Arch. Int. Yed. 16: 547-576.

Kolly, F. J., Simonsen, D. H., and Esman, R.

1948 Blood volume deternination in the hunan with red celle contalning radioactive phosphores $\left(p^{32}\right)$ and with pure human albumin.

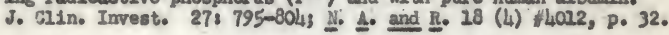

Kolner, J. A., and Boerner, F.

2945 Approved Iaborratory technique. 4th edition. D. Appleton-Century Co., New York. 1017 pp.

Kottrann, $\mathbf{x}$.

1915 Ueber dle Eestimung der Blutmenge beim Menschen und Tler unter Anwendung sines neuen Prasislonehaematoleriton. Arch. f. Exper. Path. u. Pharmakol. 11v: 356-363.

Krieger, H., Storansli, J. P., Brledell, H. L., and Holden, W. D. 2948 A comparative study of blood volume in dogs. Proc. Soc. Bxper. B10?. and Med. 68: 512-515.

Laurie, A. K.

1933 Some aspects of reaplration in blue and IIn whales. D1s. Rep. $7: 397-415$.

Lawaon, H. C., Overbey, D. T., Moore, J. C., and Shadle, O. W. 1947 Jixing of calls, plassa, and dye $\mathrm{T}-182 \mathrm{~h}$ in the eardiovascular system of barb1talised dogs. An. J. Physiol. 151, 282-289.

Lee, $F_{.} W_{\bullet}$, and Whipple, $0_{\text {. H. }}$

1921 Blood volume studles. 스. J. Physlol. 56: 328-335.

Lelchsenring, J. $\mathrm{K}_{\bullet}$, and Biester, $\mathrm{A}_{\text {. }}$

1932 Blood regeneration studies. II. Observations on the blood of normal doge with apecial reference to the measurement of volume, erythrocytes, leucocytes, and ifitrogep constituents. Am. J. Phys101. 99: 391-397. 
Lovine, G. J., Mam, W., Hodge, H. C., Ariel, I., and DuPont, 0.

194 Distribution of body weight in the tissues and organs of the rabbit. Proc. Soc. B102. and Med. 47: 318-321.

Lindhard, J.

1926a $A$ dye method for determining the blood volune in man. Am. J. Physicl. $77: 669-679$.

Indhard, J.

$1926 \mathrm{~b}$ Dyo-methods for determining the blood-volume tested in vitro. Amer. J. Physiol. 76, 497-507.

Lipganan, R. W.

1947 Blood plasmes and "dramn blood" volumes in the rat. Proc. Soc. Expt]. B101. and Med. 66: 188-191.

Lucss, W. P., and Dearing, B. Y.

1921 Blood valume in infants estimated by the vital dye zethod. Am. J. D1s. Child. 22: 96-207.

MeIntosh, R.

1929 The deternination of the circulating blood volume in infants by the CO method. J. Cl1n, Inveet. 7: 203-227.

Mayerson, H. S., Lyons, C., Parsoas, W., Nieset, R. T., Trautaan, W. V., Jr. 1948 Comparison of results of messurement of $\mathrm{A} B \mathrm{C}$ volume by direct and Indirect technies. An. J. Physiol. 155; 232-238.

MoQuarrie, I., and Davis, No. C.

1920 Blood volume as doternined by the change in refractivity of the secrum non-protein fraction after injection of certain colloids into the circulation. An. J. Physiol. 51: 257-278.

Halassez, L.

1875 Recherches sur quelques variations que présente la masse totale du sang. Areh. de Phrgiol. norm. et Path. 28 261-280.

Week, W. J., and Gesser, H. S.

1918 Blood volume. An. J. Phyriol. 473 302-317.

Netcoff, Jack, and Favor, C. B.

1944 Determination of bleod and plasma volume partitions in the grow ing rat. Amer. J. Physiol. I4I (5): 695-706.

Muller, A. T., J.

1947 A re-eraluation of the T-1824 mixing curve. Amer. J. Physiol. 151 (1) : $234-238$.

Miller, W. T.

1932 Blood volume deternination in cattle. Cornell Vet. 22, 320-332. 
lit tchell, P. H.

$1948 \Delta$ textbook of general physiology. Lth ed. NeCran-Hill Book Co., New York. 927 pp.

Mitchell, H. H., and Hamiltion, T. S.

1929 Swine type studles. III. The energy and protein requirements of growing swine and the utilisation of feed energy in growth. Univ. of nll. Agr. Bage. Sta. Bull7. No. 323, pp. 493-600.

Nachnan, H. C., James, O. W., III, Moore, J. W., and Evans, R. I.

1950 A comparative study of rod cell volumes in human subjects with radioactive phosphorus tagged red oolls and $\mathrm{T}-1824$ dye. I. Clin. Invest. 29, 258-264.

Nelson, L.

1909 Uber eine Nethode der Bestimmung der Gesantblutaenge bell Tler nebst Bemerkangen dio Veranderungen der letateren. Arch. $\underline{.}$. Exper. Path. u. Pharmakol. 602 340-344.

Hice, Lo. B., and Kats, H. L.

1934 Blood volume and hematoorit determinations in rabblts before and during emotional excitement. 스. J. Physiol. 108, 349-354.

Nitsehe, C. A., Jis., and Cohen, P. P.

1947 Simplifled deternination of blood volume. Am. J. Clin. Path. 17: 239-243.

Nolin, Chestar

1945 Blood rolume determinations with radlosetive phosphorus. Brit1sh Heart J. $7: 81-84$.

Oakley, C. L., and Warrack, G. H.

1940 The blood volume of the mouse. J. Path. and Bact. 50 (2), 372-377.

Oerum, H. P. T.

1908 Quanti tative Blutuntersuchungen. Deutsches Arch. ․ Min. Med. 93: 357-361.

Orten, J. M., Undernill, F. A., Jurrage, R. C., and Lewts, R. C.

1933 Blood volume studies in cobait polyoythends. J. Biol. Chem. 99. $457-4,63$.

Phillips, R. A., Van Slyke, D. D., Dole, V. P., Buerson, $K_{\bullet}$, Jr., Haniliton, P. B., and Arehibaid, R. M.

$1943 \mathrm{CuSO}_{2}$ method for measuring speciflo gravities of whole blood and Plasma. Eull. U. S. ArmY Hed. Dept. 71: 66-83.

Plesch, J.

1909 Hamodymantsche studiern. Zeltschr. ․․ Exper. Path. ‥ Therap. 6: $380-389$. 
Powers, J. H., Bowle, H. A., and Howard, I. H.

1930 Some observations on the blood of nornal dogs with special reference to total volune. 스. ㄱ. Phystol. 928 665-67.

Ranike, J.

187 D1e BlutverteLlung und der Tat1gkertswechsel der Organe. LeIpatg.

Rasmusgen, A. T.

1915 The $\mathrm{O}_{2}$ and $\mathrm{CO}_{2}$ content of the blood during hibernation in the wood chuck (Yarnota monsx). Am. J. Physiol. 39: 20-30.

Reeve, B. B., and Veall, N.

1949 A simplifled method for the determination of circulsting redcell volume with radiomactive phosphorus. J. Fhrsiol. 208 (1): $12-23$.

Relch, C., and Dunning, W. I.

1943 Studies on the morphology of the peripheral blood of rats. Cancer Research 3: 24,8-257.

Robertson, O. H., and Bock, A. V.

1919 Blood volume in wounded soldiers. I. Blood volume and relsted blood changes after hemorxhage. J. Bxper. Med. 29, 139-153.

Robinow, M., and Hanllton, W. F.

$1940^{\circ}$ Blood value and extracellular Rluid volum of infante and ah1ldren. An. J. D18. Ch11d. 60: 827-840.

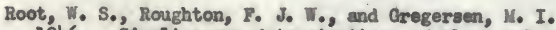

1946 Simultaneous deterninations of blood volume by $\mathrm{CO}$ and dye (T-1824) under various conditions. An. J. Physiol. 146, 739-755.

Roughton, $F_{\text {. J. }} \mathrm{W}_{\bullet}$; and Soholander, P. F.

1943 The derodeterningtion of blood gases. I. Oxygen. J. Blol. Cher. $2488541-550$.

Rowntree, L. G., Brow; O. E., and Roth, Q. M.

1929 The rolune of blood and plasma in health and disease. W. B. Saunders, Philedelphis and London, $219 \mathrm{pp}$.

Salvesen, H. A.

1919 The deternination of blood volume by the co method. J. B10l. Chem. 40: 109-125:

Schluts, F. W., Morse, M., Cessels, D. E., and Iob, C. V.

$1940^{\circ}$ A study of the nutrittonal and physical status and the response to exercise of 16 llegro boys 13 to 17 years of age. J. Pediat. 17: 466-480. 
Schurer, J.

1911 Versuche sur Bestimnung der Blutanenge durch Injection von artfremden serw. Arch. f. exper. Path. 므. Pharmkol. 66: $171-178$.

Seott, H. W., Jr., Blliott, S. R., II, and Clay, R. C.

1951. Blood volume in congenital eyanotic hoart diseases S1wultaneous measurements vith ivans blue and radioestive phosphorus. Bull. Johns HopleIns Hoap. 89, 121-132.

Seott, J. M. D., and Bareroft, J.

1924 The blood volume and the total amount of hewoglobin in anemie rats. Blochen. J. $18,2-8$.

Seott, W. J.

1938 Gas transport by the blood of the opossun, Didelphis virginianus. J. Cel1. and Comp. Phys101. 12 (3): 391-401.

Seott, W. J., Irving, L., and Safford, V.

1939 Characteristics for the transport of $\mathrm{O}_{2}$ by the blood of mink and nartin. J. Cell. and Conp. Phraiol. I4 (3): 281-286.

Sendroy, J., Jx.

1931 Wancmetric determination of henoglobin by the $\mathrm{O}_{2}$ capacity mothod. J. Blol. Chein. 91: 307-323.

Sharpe, L. M., Culbreth, G. G., and Klein, J. R.

1950 Blood and packed cell volume of the adult rat as measured by tagged cells. Proe. Soc. Bxper. B101. and Yod. 74: 681-685.

Sherrington, C. S., and Copenan, S. 1.

1893 Varlations experimentally produced in the epecifle gravity of the blood. I. Physlal. 14: 52-96.

Shohl, A., and liunter, I.

1941 The messurement of call volume of blood by the Evane blue dye method. J. Lab. and Clin. Mod. 26: 1829-1837.

Simpson, G. G.

1945 The prinotples of classlfleation and a classiflestion of mammals. BuIl. An. Hus. Nat. Hist. $85: 350 \mathrm{pp}$.

Simpson, G. G., and Roe, A.

1939 Quantitative Zoology. 18t Bd. McGraw-B111 Book Co., New Tork and Iondon. $414 \mathrm{pp}$.

Smith, H. D., Arnald, H. R., and Whipple, O. H.

1921 VII. Comparative values of Welcker $\mathrm{CO}$ and dye methods for blood volune deterninations. Accurate estination of absolute blood volume. An. J. Physlol. 56: 336-360. 
Smith, H. P.

1920 Repeated determination of blood volume at short 1ntervals by means of the dye method. An. J. Physial. 51, 221-231.

Smith, H. P., Belt, A. E., Arnold, H. Ro, and Carrier, E. Ro

1924 Blood volume changes at high altitudes. Am. J. Physiol. 71 395-412.

Spiegelberg, A., and Goheldler, H.

1872 Untersuchungen uber die Blutmenge trachtiger Hunde. Arch. I. amak. 4: 122-120.

Stanley, A. J., Hopps, H. C., and Hellbaum, A. A

1946 Observations on cobalt polyeythemia. I. Studies on the peripheral blood of rats. Proc. Soc. Exper. B101. and Med. 618 130-133.

Stelnberg, J.

1873 Uber die Bestimung der absoluten Blutnenge. Pfluger's Archiv. 1. d. gesante Phys101. 7: 101-111.

Stewrart, J. D., and Rourke, O. $\mathbb{H}_{*}$

1940 On the meserurement of extrecellular nuld volume with thiocyanate and body fluid analyses in 33 nornal individuals. J. Lab. G1in. eod. 26: 1383-1387.

Sudzuki, M.

1924 Untersuchungen uber Getaces. VIII. Uber das Blut. Toholu d. Exper. Hed. 5: 419-425.

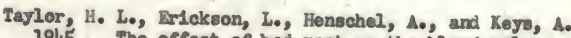

1945 The effect of bed rest on the blood valune of normal young men. An. J. Phrolol. Iili: 227-232.

Todd, C., and White, R. Q.

1911 On the fate of the red blood corpuscles when injected into the circulation of an animal of the same species with a new method for the determination of the total volume of the blood. Proc. Roy. Soe., London, Ser. B. 84t 255-259.

Trowbridge, P. F., Moulton, C. R., and Haigh, L. D.

1915 The maintenance requirement of cattle as influenced by condition, plane of nutrithlon, age, seavon, time on maintenance, type, and size of antinal. №. 토. Ixp. Sta. Res. Bur1. 18, p. 162.

Turner, C. W., and Herman, H. A.

1931 A determination of the blood and plasma volume of dalry eattile. ㅂ. Agr. Exp. Sta. Res. Bull. 159, pp. 5-61. 
Valentin, G. G.

1838 Versuche uber dile Inden thierischen Borper enthaltene Blutmenge. Repert. ‥ Anat. u. Phys1ol. 3i 281-293.

Van SI yke, D. D.

1918 Gasometric determination of the oxygen and hemoglobin of blood. J. B1.02. Chem. 33: 127-232.

Van Slyke, D. D., and Stadie, W. C.

1921 The deternination of the gases of the blood. J. B101. Chem. $49,2-42$.

Von Bohring, E. A.

1912 D10 Antitaximnethode gur Blutmenge Bestinung. Wunchen med. Vehnschr. 58: 655-660.

Wang, $C_{0} F_{\bullet}$, and Hegsted, $D_{0} M_{\bullet}$

1949 Nornal blood volume, plasma volume, and eyanate space in rats and their relation to body weight. Am. J. Physiol. 156: $228-226$.

Waterfleld, R. Lo.

1931 The effects of posture on the elroulating blood volune. I. Phys101. 72: 120-120.

Welcker, H.

1858 Bestimungen der nenge des Korperblutes und der Blutfarbekreft, so wie Bestimangen ron zahl, Masas, Oberflasche und Volume des elnsehnen Blutkorperchens beil Thieren und die Menschen. Zeitschrift fur Rat1onelle Medicin. 4i 145-167.

Went, S., and Drinker, C. $\mathrm{K}$.

1929 A micromethod for the determination of the absolute blood valuee, with data upon the blood volume of the guinea pis, whil te rat, rabbit, and eat. Amer. J. Physiol. 88: 468-478.

Wish, L., Furth, J., and Storey, R. D.

1950 Direot deterninations of plasma, cell, and organ-blood volumes In normal and hypervolemic mice. Proc. Soc. Fxper. B101. and Hed. $74(3): 64 h-648$.

Yalow, Rosalyn S., and Berson, S. A.

1951 The use of $\mathrm{I}^{42}$-tagged erythrocytes in blood velune determinations. Sel. $12 \mathrm{~W}: 1 \mathrm{H}-15$.

*Bernhart, F. W., and Stegga, L.

1943 The Iron content of erystalline human hemaglobin. J. B10l. Chen. 147: 19-22.

*Reeve, E. B.

1948 Mothods of estimating plasme and total red cell volume. Mut. Abst. and Rev. 17 (4); 811-834. 


\section{APPENDX}

The prosedures used by the author in this Investigation are described in the appendix. 


\section{APPENOIX I}

\section{PROCEDURE FOR BLOOD VOLUNE DETERMINATION}

The folloning procedure was employed in this investigation for the deterrinination of total blood volume by the use of $\mathrm{T}-1824$ (Bvans blue) dye and radionctive phosphorus-32.

1. Approxdmately $8.0 \mathrm{ml}$. of blood was withdrawn by a cardiac punoture using a heparinised syringe which was well-greased and a 2 In., no. 20 hypodermic needle. The blood was placed in a $15.0 \mathrm{ml}$. hematocrit tabe which contained a solution of heparin. I used a heparin solution which was prepared acoording to Nachnan et a․ (1950). One hundred milligrane of dried heparin was dissolved in 24.5 al. of physiological saline solution. Nachwan et 르. state that $0.05 \mathrm{ml}$. of thits solution prevents the coagulation of $5.0 \mathrm{ml}$. of blood.

2. The withdram blood was centrifuged at $3000 \mathrm{rgm}$. for 30 minutes and the hesatocrit recorded.

3. The plasma was removed from the red blood cells by a pipette and the plasia proteins were precipitated. The precipitating roagent described by Crooke and Morris (1942) was found to be very satisfactory for this purpose. The reagent was prepared by dissolving $15.0 \mathrm{gm}$. of phosphotungatic acid in $100.0 \mathrm{ml}$. of $98 \mathrm{~s}$ alcohol, shaking manually, and centrifuging at $3000 \mathrm{rpm}$. for 5 minutes in order to separate the omall amount of alcohol-1nsoluble matter. The anount of insoluble matter varied in different 
samples of phosphotungstic acid. The solution remained stable for about $\mathbb{1}_{4}$ days when stored in a dark place in a tightly-stoppered bottle. One milliliter of concentrated hydrochlorle acld with a density of 1.18 was mixed with 6.0 ml. of the alcohorie phosphotungatic acld and, if necessary, the solution was filtered. The solution, wh1ch is Ilght sensitive, must be kept alear and nust be freshly prepared each 48 hours. A blue coler develops after this time rendering the solutica worthless.

4. Two milliliters of plasna were treated with $14.0 \mathrm{ml}$. of the prec1pitating reagent, stirred mamally wh a sall, glass rod for 5 minutes, and centrifuged at 3000 spm. for 5 minutes. The optical density was read on a Klett-Sumerson photoelectric colarimeter using a fllter with a maximun trananisalon of 11ght having a wave length of 622.5 millinierons. The navimun absorption of $11 \mathrm{ght}$ of the I-182h dye is 620 to 625 millinierons. This reading is referred to as the blank resding.

5. Fifty milligans of $\mathrm{T}-1824$ dye were completely dissolved in 100.0 ml. of physlologieal saline solutiong this mixture served as the prinary dye solution.

6. Ten miluliters of this primary dye solution were diluted to 100.0 wl. Which served as the seoondary dye solution.

7. Two-tenths of a milliliter of this secondary dye solution was then added to $1.8 \mathrm{ml}$. of plasma. This soluti on of dye in plasma was deproteinated with the precipitating reagent as described in step (4). The optical density of this standard solution was read on 
the colorimeter.

8. The red blood cells fron stop (3) were washed with 10ed, physiological saline solution 3 tines and centrifuged at 3000 rpal. for 5 minutes. The supernatant was pulled off with a suction pipette after each washing.

9. Isotonic P-32 solution, contafining approximately 50 mioroeurios of activity, was added to the red blood cells until the original volume of blood whthdrawn in stop (1) was reached.

10. This suspension wae incubated for two hours in a water bath at $37^{\circ} \mathrm{C}$. The solution was stirred overy 20 to 15 minutes with a amall, glass rod.

11. The suspension was then centringed at $3000 \mathrm{rpm}$. for 5 mimutes and the supernatant was renoved by suction. The labelled cells were washed 3 times with ieed, physiologieal saline at 3000 rpan. for 5 minutes, and the supernatant was discarded after each washing. 12. Physiological saline solution was added to the washed, labelled red blood cells until the original volume of blood withdram in step (1) was reaohed. This suspensi on was stirred with a small, glass rod. \& $1.0 \mathrm{ml}$. allquot of this suspension was diluted to $200.0 \mathrm{ml}$. With distilled water. A $20.0 \mathrm{ml}$. aliquot of this salution was diluted to $200.0 \mathrm{ml}$. Wh th distilled water. This diluted mixture served as the standard solution.

13. Five milliliters of the prinary dye solution and $5.0 \mathrm{ml}$. of the labelled red blood cell suspension from step (12) were injected Into the fugular vein of the animal using a $3 / 4$ in. no. 24 needle. 
Before removing the ayringe from the veln, it was rinsed with blood two or three times.

14. Approadmately $5.0 \mathrm{ml}$. of blood was withdrewn at intervals of 5 , 10, and 20 minutes from the opposite jugular vein from that into which the Injections were made.

15. The withdram blood was placed in $15.0 \mathrm{ml}$. centrifuge tubes to which heparin had been added as in step (1). The blood was centrifuged at $3000 \mathrm{rgm}$. for 30 minutos.

16. Plaoms was separated fron the red blood cells by the use of a anall pipette. The plasma proteins of a $2.0 \mathrm{ml}$. plasma sample were precipitated as in step (4).

17. The optical density of the plasaa samples was read on the photoelectric colorimeter. The total plasns volume and the total blood volume were calculated from the formula as shom on pp. 96-97.

18. The red blood cells from step (26) were washed according to the procedure of step (11).

19. The washed red blood cells were hemolysed and diluted with distilled water to $200.0 \mathrm{ml}$.

20. The activity of the standard and sample red blood cell solutions were measured on $20.0 \mathrm{ml}$. allquots using an imserston-type Celger-litizler tube.

21. The total blood volume and the total red cell volune were calculated from the forwula as shom on page 98. 


\section{APPENDIX II}

\section{GALCULATIONS FOR THE T-1824 METHOD}

\section{Calculation of Total Plasma Volune Aceording to Cregersen (1944)}

The concentration of dye in the plasma sample obtained after the Injection of the prinary dye solution, designated here as $\left(\mathrm{C}_{2}\right)$, is to the concentration of dye in the prinary solution injected $\left(c_{1}\right)$, as the volume of the primary dye solution injected $\left(\nabla_{1}\right)$ is to the total plasma volume $\left(V_{2}\right)$. Therefore

$$
v_{2}=\frac{c_{2} v_{1}}{c_{2}} .
$$

Since the concentration of dye is directly proportional to the optical density, the equation may be written with the optical density values $D_{1}$ and $D_{2}$ may be substituted for the concentration $C_{2}$ and $C_{2}$. Therefore

$$
\nabla_{2}=\frac{D_{2} \nabla_{1}}{D_{2}} .
$$

Frow steps (5), (6), and (7) of the procedure on page 93, it may be seen that an aliquot of the prinary dye solution was diluted 100 times. The optical density of this diluted dye solution was read on the colorimeter as the standard. Therefore

$$
v_{2}=\frac{\left(D_{2} \times 100\right) v_{2}}{D_{2}} .
$$




\section{Hematocrst values}

$$
\begin{aligned}
& \text { Henatoorit red eell value }=\frac{\text { red cell volune of henatocr } 1 t}{\text { whole blood valume of hematocrit }} \\
& \text { Henatocr 1t plasma value }=(1-\text { hematecrlt red cell value })
\end{aligned}
$$

Chapin and Ross (19/42) report that the anount of plasms trapped between the red blood cells of centrlfuged blood sanples $18.5 \%$ of the total plasma. Nayerson et 르. (1948) corroberated the Iindings of Chapin and Ross. For this reason, all of the henatocrit red cell values used In the preaent Investigation were corrected by wultiplying by the factor 0.925. It follows that the Corrected hematocrit plase value $=$ ( 1 - corrected hematocrit red cell value). From these data, and from the prevloualy determined total plasma volume, the total blood rolume may be determined.

Total Blood Volune

Total blood volume $=\frac{\text { Total plasma volume }}{\text { Corrected hematocr It plastna value }}$. 


\section{APPENDTX III}

\section{CALCULATIONS FOR THE P-32 MITHOD}

\section{Total Blood Volumo}

The counts per alnute of the blood sample taken for analyals, designated here as $(s)$, is to the counts per minute of the injected solution (I), whlch may be calculated fros data firen in step (12) of the proeedure on page 94 , as the valune of the blood sangle $\left(\nabla_{1}\right)$ is to the total blood volume $\left(\nabla_{2}\right)$. Therefoce

$$
V_{2}=\frac{I V_{2}}{s} .
$$


APPENOIX IV

PROCELURE FOR RED BLOOD GELL COUNT

Procedure used in the present investigation for counting red blood cells according to Kolwer and Boecrner (1945):

1. Draw blood to the 0.50 aerk in the Thora pipette.

2. Draw in Hayme's diluting fluid to the 102 mark while roteting the pipetto.

3. Place a coverglass over the ruled area of a Levy-Hauser counting chamber.

4. Wipe off the fIrat drop of diluted blood and allow the next drop to flow under the coverslip without fuling the trough. Aulow 3 minutes for the blood cells to settle.

5. Use the "bright Iight" counting chamber and count the number of red blood celle in 8 small squares in a horisontal row and in 10 sand squares in a vertical row to get a total of 80 small aquares counted. Count only the red blood cells on the top and lert IInes and those inside the squares.

6. Count the red blood cells on the lower part of the counting chamber as was done in step (5) and average the two counts.

7. Add 4 eiphers to the average found in stop (6) which gives the number of red blood cells per cuble millineter of blood. 


\section{APPENDIX V}

\section{HEMOCLOBIN DGMERUIMATION}

Procedure used in this investigation for the dotermination of henoglobin on the Fisher Blectro-hemoneter:

1. Mill pipette to the mark "20" IIne with blood.

2. Add $0.1 \mathrm{~N}$ hydrochloric acld to the upper Ilpette "fluled" aark. The atandard dilution is 20 cuble millimeters of blood in 5.0 ml. of $0.1 \mathrm{~N}$ hydrochloric acid.

3. Hemolyse for at least 30 minutes.

4. Adjust the hemometer to read zero.

5. Adjust the reading to sere with the standard cell in place.

6. Read the per oent henoglobin or $g / 200$ ec. of henoglobin with the ample in plaee. 


\section{APPEMIX VI}

\section{APPARATUS USED IN THE SKRINOS METHOD}

A procedure for the determination of the exygen capecity of the blood as deseribed by Roughton and Scholander (19433) and aodifled by Orant (1947):

The Instrument used in the syringe method deseribed by Roughton and Scholander (1943) conslsts of "a $1 \mathrm{cc}$. pyrex tuberculin syringe, with arresting elip on the plunger to prevent it from slipping and with a standard preciad on bore $0.5 \mathrm{~mm}$. pyrex eapillary fused to 1 ts nozzle. The top of the eapillary is expanded to a cylindrical oup of about $2.5 \mathrm{~mm}$. bore and $1.5 \mathrm{~cm}$. length." The distance between the two marks on the cup is approcimately $5 \mathrm{~mm}$. The blood pipette is made fron thin-walled glass tubing ( 1.0 to $1.5 \mathrm{~m}$. bore) and It is ground amooth at the tip so as to fit smigly 1nto the botton of the glass cup. This pipette is calibrated so as to deliver 39.3 cuble m. which is equal to 100 divisions of the eapillary, and also 43.3 ce. A detachable rubber cup of about $1.0 \mathrm{cc}$. capacity is fitted to the top of the glass oup. Five 5 cc. and one $10 \mathrm{cc}$. syringe are necessary for storing and delivering reagents. 


\section{APPBDIX VIT}

\section{REAOENTS USED IN THE SYRIME ITSTOD}

1. Distilled water.

2. 0.9 per cent sodius chloride.

3. Caparylic alcohol.

4. Ferrleyanide solutions

12.5 gx. of potassium ferricyandde

3.0 gm. of potassium blcarbonate

0.5 gne of saponin

These substances are dissolved in water and made up to $50.0 \mathrm{cc}$. The solution should not be used for mare than 3 davs; otherwlie appreciable 2088 of carbon dicetde nay occur.

5. Acetate buffer:

70.0 ga. of sodiun acetate, $\mathrm{NaC}_{2} \mathrm{H}_{3} \mathrm{O}_{2} \cdot 3 \mathrm{H}_{2} \mathrm{O}$, are dissolved in $100 \mathrm{oc}$ of distilled water and $15 \mathrm{cc}$. of glacial scotie act are addod.

6. 45 per cent urea.

7. 20 per cent sodiun hydrocide.

8. Pyrogallar salutions

25.0 gm. of pondered pyrogallol are added to 200 ec. of 20 per cent sodium hydroxide in a rubber-stoppered bottle and covered with a layer of oll $2 \mathrm{om}$. thick on top. The pyrogallol is difsolved under the ofl by stirring with a glass rod. 
Reagents 3, 4, 5, 6, and 8 are conveniently stored in 5 cc. syringes, and reagent 7 in a 10 cc. syringe. The syringes have fine-tipped glass nossles attached and the rear part of the plungers are well greased.

9. Heparin. 


\section{APPENDIX VIIS}

\section{PROCEDURE WITE THE SKRINAE METHOD}

1. Blood was aucked directIy into the 39.3 cuble millimeter pipette which had been previously Aushed with anti-coagulant solution (hepar1n) and dried in a current of adr. Blood was taken d1reetly from a ressel or the blood was collected in a paraffin block which contal ned eup-shaped cavities.

2. The $1 \mathrm{cc}$. syringe was Iushed 3 times with separate portions of saline, emptied, and the cup ruled to the lower mark with saline.

3. The tip of the plpette containing the blood was passed carefully Into the cup which contained saline and pressed Mrmily against the botton.

4. Blood was suoked into the wringe by a mooth withdrawal of the plunger. Once the pipette was enptied, it was quickly removed and the saline in the cup was drawn in after the blood.

5. The blood-saline mixture was lowered far enough into the ayringe to pernit entry of an alr volume of appreximately 1.0 cuble centimetors.

6. The syminge was rotated on 1ts long axls with an oceastonal rotation at rlght angles to apread a small layer of bleod on and over the inside of the syminge and thus ensure uniform exposure of blood to the air. Once a mirute during this 5 mimute procedure the alr was renewed by alternately running the blood up to the caplillary and lowerling to the $1.0 \mathrm{cc}$. mark. 
7. Two capllary divisions of eaprylle alcohol was added which provented the formation of transverse blood f1lms whlch made the expulation of afr without loss of blood differilt.

8. Nir was expelled and the blood-saline mixture was pushed up to the botton of the cup. The cup wa fllled to the upper wark with ferrieyanide solution, and the solution was then lowered to the botton of the cup.

9. The eup silled to the upper mark with acetate buffer and the latter was dram down to the bottan of the cup.

10. The cup was then 1mediately ellled to the top with 45 per cent urea, and then alosed firmly with the ringer.

11. The closed apparatus was vigorously shalen in the horisontal position and the plunger was gracually drawn out as the carbon dlocide and other gases were evolved, wh the pressure in the syringe kept roughly at exditing pressure. A volume of about 0.75 ce. of gas was evolved by shalding for about 2 minutes.

12. The syringe plunger was manipulated so as to keep the gas aeniscus In the capillary as the IInger was gradually released. A snall amount of ures was allowed to run don into the caplllary and left there until the walls were perfectly alean.

13. Three-fourths of the urea solution in the elass cup ms removed, and the rubber cup was fltted in place and FIlled with 10 per cent sodium hydroxdde without trapping air bubbles.

14. A I1ttle sodium hydroxide was drawn into the syringe. This absorbed some oarbon dioxide, causing a partial vacuum which quickly 
sucked in more sodium hydroctde patil only a anall bubble consisting of exysen, nftrogen, and carbon monoxide was left at the top of the syringe. The abrorption took a few seconds and Just before it was completed the residual bubble was sarewed slowly and carefully up into the caplllary by manipulation of the plunger.

15. The rubber cup was renoved and the glass cup enptied.

16. The capillary was placed for one-half mimite in a beaker of water at roon temperature.

17. It was then removed, dried by light wiplng, and care was taken that the capillary was not handled, and the volune of the bubble read, and recorded as $\nabla_{1}$ divlsions.

18. The glass cup was then IIIled with pyrogallol solution and the axgren of the bubble was absorbed by pulling the gas bubble down to the bottom of the sapillary and back agaln a fer times unt.ll the reading was constant. Finally the bubble was moved very slowly up into the top part of the caplllary and after a further temperature equilibration Its volune was read again and recorded as $\nabla_{2}$ divisions.

To obtain a blank value for the reagents as woll as for physically dissolved axygen of the blood, an analysis is performed exactly as doscribed in the procedure, but Instead of delivering the usual 39.3 cubio millimeters of blood, 43.3 cuble mdliseters of 0.9 per cent sodium chloride is substituted. Sendroy ot al. (2934) have shown that $1.1 \mathrm{sc}$. of 
aerated saline solution contal ns the same volune of physically dissolved oxygen as $1.0 \mathrm{cc}$. of blood. The procedure is continued as $1 f$ blood were used 1 notead of sel ine oolution.

To wash the instrument, the plunger is palled out under a stream of running water and the blood mixture poured out. The syringe $1 \mathrm{~s}$ Illed and emptied several times with water before the plunger is restored. The plunger ahould never be forced imwands if there is a reaistance due to precipitation. Oceasionaly, the whole syringe should be rinsed with dichromate solution. The time necessary to run a sample is about 12 minutes.

In the messurement of the bubbles it is essential to move them very slowly and evenly so as to ssoure good drainage. These delleate adjustments are readily made by rotating the plunger gentily with a screwing motion as it is being drawn in or out. Slipping back of the plunger is prevented by a proper adjustment of the arreating olip. Carerul control of the movement of the bubble 1s secured by using the 11ttle IInger as a brake against the plunger. 


\section{APPENDIX IX}

CALCULATIONS OP OXYCEN CAPACITY WITH THE SXRINOE METHOD

$$
\begin{aligned}
\text { Volune } & =P 1 x^{2} \mathrm{~h} \\
& =3.2416 \times(0.25)^{2} \times 100 \\
& =19.6350 \mathrm{amm} \text {. total volume of eapillary. } \\
\frac{19.6350}{50} & =0.39270 \mathrm{cmm} \text {. per diviaion of eap111ary. }
\end{aligned}
$$

1 division of eapillary $=2.0 \mathrm{~mm}$.

The caplulary 1s marked off in 50 divialons.

$50 \times 2=200 \mathrm{~m}$. = length of capillary.

Dianeter of caplilary $\equiv 0.5 \mathrm{~m}$.

axygen content $=\left(v_{1}-\nabla_{2}-0\right) \times s$

$v_{1}=$ length of gas bubble before pyrogallal is added.

$v_{2}=$ length of gas bubble after pyrogallol is added.

- correction of axysen content of reagents as doterralned by the blank.

I = correction factor for temperature, aqueous vapor presaure, and the barconetrie pressure. This factor may be read from a table such as that given by Poters and Van Slyice (1932) volume 2,129 , Table 25 . 


\section{BIOCRAPHY}

Jack Denung Burke was born April 24, 1919, in Clarksburg, Weat Virginia. He attended elementary schools in Cherleston, West Virginla, and was gracuated from Woodrow WIIson High School In Beokley, West Virginla, in 1937. He attended Blue Ridge School for Boys in Hendarsonville, North Carolina, from 1937 to 1938, and West Virginia Wesleyan College In Buclchamon, West Virginia, Iroan 1939 to 1940.

He was emplogred by E. I. du Pont de Nenours Compung In Belle, West Virginla, from 2940 to 1945 at which time he entered the U. S. Naval Reserve. He served on active duty unt1l April, 1946.

Fie entered the Univershty of Tennessce at Inourville in June, 1946, and received the Bachelor of Arts degree in 1948. The laster of Sclence degree was awarded in 2949 by West Virginia Univeralty in Morgantorm, West Virginis. He entered the University of Mlorids in June, 1949, in order to contimas his graduate studies.

He was appointed a graduate assistant in blology in July, 1950, and held that appointment unt1l September, 1951. At that time he wes appointed a teaching assistant in blalogy and fllled that position until Jane, 1952.

He is a member of the Phi Sigma Blological Society, Ameriean Association for the Advancement of Science, Assoclation of Southesstern Blologlats, and the Korlda Acadeny of Sclences. Hie is a 32nd degree Hason, a Shriner, and a member of the Lambda Chl Mlpha social Iraternity. 
This dissertation was prepared under the direction of the chalrman of the candidate's supervisory conalttee and has been approved by all members of the connittee. It was subnitted to the Dean of the Callege of Arts and Sclences and to the Craduate Counc1l and was approved as part1al fulfuliment of the requirements for the degree of Doctor of Philosophy.

June 9, 1952

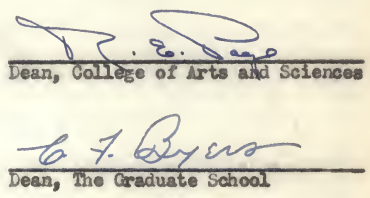

SUPERVISORY COMAITTEE:

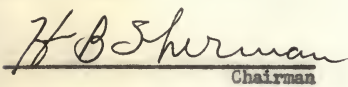

dicleles
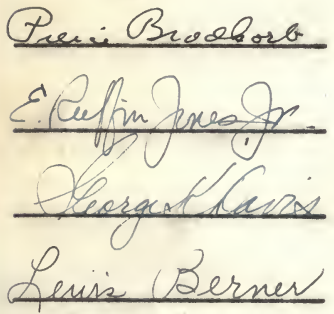